\title{
U. S. GEOLOGICAL SURVEY RADIOCARBON DATES VIII*
}

\author{
BETSY LEVIN, PATRICIA C. IVES, CHARLES L. OMAN \\ and MEYER RUBIN \\ U. S. Geological Survey, Washington, D. C.
}

This list contains the results of measurements made during 1.963 and 1964. Samples are counted in the form of acetylene gas, as previously, and ages computed using the Libby half-life of $5568 \pm 30 \mathrm{yr}$. The error listed is always larger than the one-sigma statistical counting error commonly used, takes into account known uncertainty laboratory factors, but does not include external (field or atmospheric) variations.

Unless otherwise stated, collectors of all samples are members of the U.S. Geological Survey.

\section{SAMPIF DESCRIPTIONS}

\section{A. Eastern U. S.}

\section{Warm Mineral Springs series, Florida}

Charcoal from stratified marl on ledge $45 \mathrm{ft}$ below surface of spring now discharging connate water, Warm Mineral Springs, Sarasota County, sec. 24, T 39 S, R 20 E ( $27^{\circ} 03^{\prime} 35^{\prime \prime}$ N Lat, 82 $15^{\prime} 38^{\prime \prime}$ W Long), Florida. Coll. 1962 and subm. by H. K. Brooks, Univ. of Florida, Gainesville. Comment (H.K.B.) : deposit represents history of spring from an open sink to the present flowing connate spring, material being deposited on the ledge as water table rose in postglacial time. W-1243 represents last phase in rising of water table just before black organic oozes of the connate spring began to accumulate; it is assumed sealevel was approaching its present position. W-1241 represents a stage in which fresh water stood in the sink above the ledge. W-1245 and W-1242 represent phases when sealevel was (est.) ca. $90 \mathrm{ft}$ lower than now. W-1153 is from zone largely subaerial in origin and marks begimning of deposition.

\section{W-1243. Charcoal, top}

$8520 \pm 400$ 6570 в.c.

Sample coll. from top of stratified subaerial and fresh-water marl.

W-1241. Charcoal, -37 ft

$8600 \pm 400$

6650 в.с.

Sample coll. from middle zone of fresh-water marl, alt $-37 \mathrm{ft}$.

\section{W-1245. Charcoal, $-38 \mathrm{ft}$}

$9370 \pm 400$

7420 в.C.

Sample coll. at alt $-38 \mathrm{ft}$. This zone is transitional to fresh-water marls of zone above, and still contains many plant remains and terrestrial vertebrate bones.

\section{W-1242. Charcoal, $-38.5 \mathrm{ft}$}

From predominantly fresh-water marl.

$9500 \pm 400$

7550 в.с.

* Publication authorized by the Director, U. S. Geological Survey. 
Betsy Lavin, Patricia C. Ives, Charles L. Oman and Meyer Rubin 373

\section{W-1153. Charcoal, $-39 \mathrm{ft}$}

$9870 \pm \mathbf{3 7 0}$

7920 в.C.

From impure marl and travertine containing large amounts of wood and leaves.

\section{W-1306. Penobscot Bay, Maine}

$7390 \pm 500$

$\mathbf{5 4 4 0}$ в.c.

Wood from $N$ part of Penobscot Bay $\left(14^{\circ} 25^{\prime} 22^{\prime \prime} \mathrm{N}\right.$ Lat, $68^{\circ} 49^{\prime} 58^{\prime \prime} \mathrm{W}$ Long), Maine, core sample just above prominent sub-bottom reflecting horizon, fairly continuous throughout bay. Horizon represents sandy, pebbly zone in marine silts and clays, overlying glacial sediments and bedrock, and extending to present water bottom. Sandy, pebbly zone formed during an emergent phase of bay sedimentation. Coll. 1959 by R. L. Cory; subm. by C. Ostericher, U. S. Navy Oceanographic Office, Suitland. Maryland. Comment (C.O.) : date defines upper limit of age of emergence.

\section{Barnstable series, Massachusetts}

Peal cut from vertical marsh bank on NW side of Scorton Creek opposite $S$ end of Wicks Istand. Great Marsh, Barnstable $\left(41^{\circ} 43^{\prime} 36^{\prime \prime} \mathrm{N}\right.$ Lat, $70^{\circ} 21^{\prime}$ $39^{\prime \prime}$ W Long), Massachusetts. Bank is composed of successive layers of peat formed at intertidal levels and capped with thin layer of high marsh peat. Layers of sandy silt alternate with layers of fibrous silt, the layers increasing in thickness downward and underlain by hard sand $6.7 \mathrm{ft}$ below marsh surface. Coll. 1963 by A. C. Redfield, B. Levin, and T. K. Newbury; subm. by B. Levin. Comment (A.C.R.) : dates give rate of accumulation of peat during intertidal stage when accumulation depends on sedimentation rate rather than change in sealevel. Accumulation rate is $6.9 \times 10^{-3} \mathrm{ft} / \mathrm{yr}$, rise in sealevel is $3.3 \times$ $10^{-3} \mathrm{ft} / \mathrm{yr}$ (Redfield and Rubin, 1962). With 60 layers in $610 \mathrm{yr}$, stratificalion does not represent annual growth.

W-1342. Upper peat

Sample coll. 0.9 to $1.1 \mathrm{ft}$ below surface of marsh.

\section{W-1319. Lower peat}

Sample coll. 5.1 to $5.3 \mathrm{ft}$ below surface of marsh. Distance hetween centers. $4.2 \mathrm{ft}$.

\section{W-1187. Zacks Cliff, Martha's Vineyard, $\quad 15,300 \pm 800$ Massachusetts \\ 13,350 в.C.}

Leaves, needles, fruits, etc. from thin-bedded gray silty clay, base of Zacks Cliff, Gay Head, Martha's Vineyard $\left(41^{\circ} 40^{\prime} \mathrm{N}\right.$ Lat, $70^{\circ} 50^{\prime} \mathrm{W}$ Long). Massachusetts. Coll. 1962 and subm. by C. A. Kaye. Comment (C.A.K.) : clay overlies middle Wisconsin solifluction gravel and compact till of early Wisconsin age. Date supports interpretation that clay is probably associated with the next drift (late $W$ isconsin), which does not overlie the clay-sand sequence in this stretch of cliff. 


\section{Quaker Basin series, New York}

Peat from small elongate swamp $31 / 2 \mathrm{mi}$ SE of De Ruyter village, SW Madison County (42 $40^{\prime} 30^{\prime \prime} \mathrm{N}$ Lat, $75^{\circ} 50^{\prime} \mathrm{W}$ Long), New York. Coll. 1962 and subm. by C. D. Holmes, Univ of Missouri, Columbia. Comment (C.D.H.) : date obtained for W-1230 represents carly postglacial for this locality. W-1231 is problematical: date is Hypsithermal and may represent mostly the woody portion; pollen from the matrix (nonwoody portion) records a cold interval perhaps several hundred yr carlier.

\section{W-1230. Silty peat}

$10,650 \pm 300$ 8700 B.C.

Diatom-rich silt with rootlets and other vegetal remains coll. from base of swamp deposit, at depth of 11 to $11.5 \mathrm{ft}$.

\section{W-1231. Woody peat}

$6300 \pm 300$ 4350 в.C.

Sample coll. from "log zonle" +1 ft higher in section than W.1230. Pollen analysis indicates a return to $95 \%$ coniferous pollen following an interval during which elm-birch-maple had become common.

W-1389. Washington, D. C.

$>38,000$

Oak $\log$ from excavation $S$ of Virginia Ave. hetween 25th and 26th St., N.W., (39 $00^{\prime}$ N Lat, $77^{\circ} 02^{\prime}$ W Long), Washington, D. C. From an irregular depression on surface of baesment rocks underlying $2 \mathrm{ft}$ sandy clay, $23 \mathrm{ft}$ iron. stained gravel, and $6 \mathrm{ft}$ fill at top. Coll. 1963 by Russell Morris; subm. by Henry W. Coulter. Comment (H.W.C.) : dates the basal clay, a continuous stratigraphic horizon in the area bounded hy Pennsylvania Ave., Constitution Ave., and Rock Creek.

\section{B. Central U. S.}

\section{Big Bone Lick series, Kentucky}

Samples of wood from Big Bone Lick Salt Spring, 2 mi E of Ohio River, Boone County ( $38^{\circ} 52^{\prime} 32^{\prime \prime}$ N Lat, 81 ${ }^{\circ} 45^{\prime} \mathrm{W}$ Long), Kentucky. Coll. 1963 and subm. by F. C. Whitmore. Comment (F.C.W.) : date of W-1358 prohably indicales aye of the following mammals recovered from the same level in the excavation: Equus cf. complicatus. Mylodon sp., Mammut americanus, and Mammuthus sp. W-1357 came from same horizon as W-908, <250 (USGS V1). Young date may he due to reworking as evidenced by the mixed assemblage in the same horizon containing the Adena pendant (see below), worn prohoscidean hones, relatively frosh bones of Bison bison, and the wood.

W-1358. Wood with tusk

$10,600 \pm 250$ 8650 в.c.

Wood asociated with prohoscidean tusk near top of gray silty clay a few inches below oxidized zone.

\section{W-1357. Wood with bones}

Sample from near top of gravel layer containing abundant bones of Bison bison as well as Ovibos, Cervus cf. cunadensis, and Odocoileus sp. From same level as slate pendant id. as representing the Adena Indian culture of 1500 to 2000 B.p. 


\section{W-1353. Reidland, Kentucky}

$21,080 \pm 400$

19,130 в.c.

Small gastropod and pelecypod shells, 3/1 mi NE of Reidland, McCracken County $\left(37^{\circ} 00^{\prime} \mathrm{N}\right.$ Lat, $88^{\circ} 34^{\prime} \mathrm{W}$ Long), Kentucky, coll. from silt, probably accumulated in a lake dammed by rapid alluviation downstream. Damming caused Tenne'ssee River to be diverted for short time to flow northward into Ohjo River which occupied Cache Valley. Coll. 1963 and subm. by W. W. Olive. Comment (W.W.O.) : date indicates Tazewell age for the sediments.

\section{W-944. West Feliciana Parish, Louisiana \\ $12,740 \pm 300$ 10,790 в.с.}

Wood from sediments along Tunica Bayou, believed to be late Pleistocene louried valley, NW $1 / 4$ NE $1 / 4$ sec. $78, T$ I S, R 4 W $\left(30^{\circ} 56^{\prime} \mathrm{N}\right.$ Lat, $91^{\circ} 32^{\prime} \mathrm{W}$ Long). West Feliciana Parish, Iouisiana (Fisk and others, 1938). From sand and silt with wood and mastodon bones; max. $15 \mathrm{ft}$ thick, overlain by loess and underlain by Miocene clay. Similar buried valleys are found in area adjacent to Mississippi River. Coll. 1961 hy C. O. Morgan; subm. by R. R. Meyer. Comment (R.R.M.): prairie terrace adjacent to stream has been thought early Wisconsin age (Fisk and McFarlan, 1955). This was an attempt to establish relationship hetween dated deposits and the principal shallow acquifer in SE L.ouisiana.

\section{W-1281. Lake Charles, Louisiana}

$>42,000$

Crude oil from oil well (Miller 15A). Lockport Field, Lake Charles, Calcasieu Parish, SE comer SW $1 / 1$ NE1/4 sec. 9, T 10 S, R 9 W $\left(30^{\circ} 13^{\prime}\right.$ N Lat. $93^{\circ} 17^{\prime}$ W Long). Louisiana, from Pliocene oil sand at $1050 \mathrm{ft}$ depth. Coll. 1963 and subm. by A. L. Hodges. Comment: split samples of this oil were dated hy two commercial labs., resulting in $\mathrm{C}^{14}$ ages of $28.600 \pm 1380 \mathrm{yr}$ from one lab. and $>37,000 \mathrm{yr}$ from the other. Present date represents a check.

\section{Lake Charles series, Louisiana}

Wood fragments from Chicot aquifer, ca. $9 \mathrm{mi} \mathrm{SW}$ of Lake Charles, Calcasieu Parish, sec. 19, T $10 \mathrm{~S}, \mathrm{R} 9 \mathrm{~W}\left(30^{\circ} 12^{\prime} \mathrm{N}\right.$ Lat, $93^{\circ} 20^{\prime} \mathrm{W}$ Long). Louisiana. From Pleistocene sand and gravel in which dissolved methane occurs locally to the extent ca. $50 \mathrm{ppm}$. Dates indicate methane is not generated from organic material contained in the aquifer, but is derived from a nearby oil field (see W-1281, this date list.).

W-1270. Wood fragments, $220 \mathrm{ft}$

W-1269. Wood fragments, $425 \mathrm{ft}$

W-1271. Wood fragments, $520 \mathrm{ft}$

\section{John Ball Park series, Michigan}

$$
\begin{aligned}
&>42,000 \\
& 850 \pm 200 \\
& \text { A.D. } 1100 \\
& 12,820 \pm 400 \\
& 10,870 \text { в.c. }
\end{aligned}
$$

Samples from peat bed and wood from till overlying it, exposed highway cut $\mathbb{W}$ of Grand River on distal slope of outer Valparaiso Moraine, John Ball Park, Grand Rapids (42 $58^{\prime} \mathrm{N}$ Lat, $85^{\circ} 42^{\prime} \mathrm{W}$ Long), Michigan. Peat forms 
distinct layers with interbedded calcareous marl, silt, and sand, is overlain by outwash and Valparaiso Till of the Lake Michigan Lobe, and underlain by $13 \mathrm{ft}$ of lacustrine sand with limonite, which in turn are underlain by laminated clay, silt, and sand. Coll. 1963 and sulmm. by J. H. Zumberge, Grand Valley State College, Allendale, Michigan. Comment: an attempt at maximum date for outer Valparaiso moraine and to determine time interval between the two ice advances responsible for the lower and upper till.

W-1293. Lowest peat layer

$>36,000$

Lumps of black amorphous organic material from lowermost 2 to 4 in. of peal.

W-1292. Main peat layer

$>40,000$

Peat containing wood fragments from basal one in. of main peat layer.

\section{W-1294. Upper peat layer}

$>40,000$

Peat from layer highest in section; pollen is high in spruce.

W-1300. Wood

$>40,000$

Wood from till overlying peat complex, ca. 15 to $20 \mathrm{ft}$ above top of peat.

\section{W-1414. Porcupine Mountains, Michigan \\ $10,230 \pm 500$ 8280 в.C.}

Spruce $\log$ from Porcupine Mountains State Park, Gogchic County, SW 1/4. SW 1/1 sec. 13, T $50 \mathrm{~N}, \mathrm{R} 45 \mathrm{~W}\left(46^{\circ} 41^{\prime} \mathrm{N}\right.$ Lat, $89^{\circ} 53^{\prime} \mathrm{W}$ Long), Michigan. Sample from depth $13.5 \mathrm{ft}$, in a red clay till. Coll. by B. Taarola and M. skovera, Michigan State Highway Dept.; subm. by R. W. Kelly, and A. E. Slaughter, Michigan Geol. Survey, Escanaha. Comment: till this young in Lake Superior basin is difficult to explain. No obvious error in interpretation, however.

\section{Spider Creek Bog series, Minnesota}

Lake sediment cores from $N$ side Spider Creek Bog, SW1/1. NW1/1 sec. 29, T $52 \mathrm{~N}, \mathrm{R} 18 \mathrm{~W}, 4 \mathrm{mi} \mathrm{W}$ of Alborn $\left(47^{\circ} 58^{\prime} \mathrm{N} \mathrm{Lat}, 92^{\circ} 39^{\prime} \mathrm{W}\right.$ Long), St. Louis County, Minnesota. Coll. 1962 by H. E. Wright and R. C. Baker; sulbm. hy H. E. Wright, Univ. of Minnesota, Minneapolis. Comment (H.E.W.) : site open for sedimentation soon after retreat of Mankato ice of St. Louis sublobe. Basal sample (W-1233), intended to date this event, probably was contaminated with fragments of Cretaceous lignite. Similar contamination was probably present in W-1234, intended to date advent of closed forest into a region occupied by spruce park-tundra prior to this time.

\section{W-1233. Core, 974 to $980 \mathrm{~cm}$}

$22,000 \pm 600$ 20,050 в.с.

Calcareous silty sand with fine plant litter, containing nonarboreal tundratype plant macrofossils and spruce pollen (id. by R. G. Baker).

\section{W-1234. Core, 887 to $890 \mathrm{~cm}$}

$$
\begin{aligned}
& 13,000 \pm 400 \\
& 11,050 \text { в.с. }
\end{aligned}
$$

Silty marl with shells and organic debris; pollen shows birch maximum. Base of zone contains spruce and birch macrofossils (id. by R. G. Baker). 


\section{W-1232. Swanville, Minnesota}

Plant litter from $\mathrm{N}$ side of road cut $2.5 \mathrm{mi}$ W of Swanville, Todd County, $\mathrm{VE} / / 4 \mathrm{SW} / \mathrm{s}$ sec. $32, \mathrm{~T} 129 \mathrm{~N}, \mathrm{R} 32 \mathrm{~W}\left(45^{\circ} 56^{\prime} \mathrm{N}\right.$ Lat, 9.1 $44^{\prime} \mathrm{W}$ Long $)$, Minnesota. From hase of 1.2-m unit of organic silt with peat and sand, overlying gray calcareous till of Wadena lobe, believed to correlate with Cary (Wright, 1962), and underlying silt and shale-bearing calcarcous silty till of Des Moines lobe (Mankato). Coll. 1960 and subm. by H. E. Wright. Comment (H.E.W.) : date is too old according to present correlation of drifts.

\section{W-1433. Apple Creek Valley, North Dakota}

Pelecypod and gastropod shells from roadeut, NE1/1. SW1 $1, \mathrm{SW} 1 / 4$ sec. 34. 'T $139 \mathrm{~N}, \mathrm{R} 79 \mathrm{~W}\left(17^{\circ} 30^{\prime} \mathrm{N}\right.$ Lat, $100^{\circ} 38^{\prime} \mathrm{W}$ Long), Burleigh County, North Dakota, from glaciofluvial sand (Napoleon drift) overlying bedrock (Kume. and Hansen, 1964). Coll. 1962 by Jack Kume and P. G. Randich; subm. by P. G. Randich. Comment (P.G.R.) : date supports conclusion that Napoleon drift is of lower part of Wisconsin Glaciation. Date compares well with that of W-990, but not with that of W-1015 (CSGS VII), both thought to represent Napoleon drift in Logan County.

\section{Burleigh County series, North Dakota}

Pelecypod and gastropod shells from Burleigh County, North Dakota. Shells occurred in collapsed kettle rim lacustrine sediments which are part of Burnstad drift. Coll. 1962 hy Jack Kume; subm. by P. G. Randich. Comment (P.C.R): these dates support conclusion that Burnstad drift is of upper part of Wisconsin Claciation, and agree with previous dates obtained on Burnstad drift in other areas of North Dakota-W-512, 11,480 \pm 300 (USCS V); W.954, $9870 \pm 290, W-956,11,070 \pm 300, W-974,11,650 \pm 310$, and WV $-1019,9000 \pm 300$ (CSGS VII)

\section{W-1434. Test hole 2051}

$10,100 \pm 300$

8150 в.C.

Shells from NEl/, NEY/ NW $1 / 4$ sec. 12, T 114 N, R 79 W $\left(17^{\circ} 19^{\prime} \mathrm{N}\right.$ Lat, $100^{\circ} 37^{\prime} \mathrm{W}$ Long).

\section{W-1436. Test hole 2056}

$9990 \pm 300$

8040 в.с.

Shells from NE1/4. NE1/4 SEl/4 sec. 19, T $143 \mathrm{~N}, \mathrm{R} 75 \mathrm{~W}$ (47\% $13^{\prime} \mathrm{N}$ Lat, $100^{\circ} 13^{\prime} \mathrm{W}$ Long).

\section{W-1369. Foster County, North Dakota}

$9860 \pm 400$

7910 в.c.

Coniferous wood from excavaled well, NE $1 / 4$ NW $1 / 4$ sec. 32, T $146 \mathrm{~N}$, R $67 \mathrm{~W}\left(17^{\circ} 26^{\prime} 00^{\prime \prime} \mathrm{N}\right.$ Lat, $99^{\circ} 14^{\prime} 30^{\prime \prime} \mathrm{W}$ Long), Foster County, North Dakota, from 20-ft deep excavated well bottomed by Pierre Shale overlain by fossiliferous zone, containing cones, wood branches, and mollusks, in turn overlain by $18 \mathrm{ft}$ of till of Grace City ground moraine. Coll. 1963 by R. J. Kresl; sulım. by W. M. Laird, North Dakota Geol. Survey, Grand Forks. Comment: date is maximum for Grace City ground moraine in this area. 


\section{W-1432. Missouri River, North Dakota}

$$
\begin{array}{r}
210 \\
\text { A.D. } 1740
\end{array}
$$

Wood from test hole in Missouri River floodplain, SW $1 / 4$ NW $1 / 4$ NE1/4. sec. $24, \mathrm{~T} 137 \mathrm{~N}, \mathrm{R} 80 \mathrm{~W}\left(46^{\circ} 40^{\prime} \mathrm{N}\right.$ Lat, $100^{\circ} 43^{\prime} \mathrm{W}$ Long), Burleigh County, North Dakota. Stratigraphy in Missouri River Terrace 1, top to bottom: clay; sand with wood fragments and snail shells (sample); gravel; gravelly sand. Coll. 1961 by Roger Schmid; subm. by P. G. Randich. Comment (P.G.R.) : date indicates deposition of sediments of Terrace 1 are very recent.

\section{Sheyenne River series, North Dakota}

Wood and charcoal from cut bank of Sheyenne River, Richland County, NW $1 / 4$ NW1/4 SW1 14 , sec. 4 , T $135 \mathrm{~N}, \mathrm{R} 52 \mathrm{~W}\left(46^{\circ} 32^{\prime} 20^{\prime \prime} \mathrm{N}\right.$ Lat, $97^{\circ} 14^{\prime} 15^{\prime \prime}$ W Long), North Dakota. Stratigraphy, top to bottom: sand with few gastropod and pelecypod shells; clay with abundant shells, fragments of bone and waterworn bits of charcoal; sand; clay (W-1181); sand (W-1185). Coll. 1962 and subm. by J. A. Brophy, North Dakota State Univ., Fargo. Comment (J.A.B.) : date of W-1185 coincides with the apparently world-wide climate at end of Hypsithermal interval. W-1184, appears to be anomalous.

\section{W-1184. Charcoal}

\section{W-1185. Wood}

\section{Traill County series, North Dakota}

Wood fragments from gravel pits in Traill County, North Dakota, from zone containing water-worn branches, twigs, and fine-grained carbonaceous material. W-1360 is from Hillsboro beach complex (Upham, 1895), which overlies lacustrine silt and clay of Lake Agassiz. W-1361, 41/2 mi W of W-1360. is from Blanchard beach complex (Upham, 1895). Coll. 1961 and subm. by H. M. Jensen. Comment: sample from gravel pit nearby gave $10.050 \pm 300$ (W-1005, USGS VII).

\section{W-1360. Hillsboro wood}

$9810 \pm 300$ 7860 в.с.

Sample from NW1/4 SE $1 / 4$ SE $1 / 4$ sec. $18, T 147 \mathrm{~N}, \mathrm{R} 50 \mathrm{~W}\left(47^{\circ} 38^{\prime} \mathrm{N}\right.$ Lat, $97^{\circ} 05^{\prime} \mathrm{W}$ Long).

\section{W-1361. Blanchard wood}

Sample from NW1/4 SE $1 / 4$ SW $1 / 1$ sec. 21 , T $147 \mathrm{~N}, \mathrm{R} 51 \mathrm{~W}\left(47^{\circ} 37^{\prime} \mathrm{N}\right.$ Lat, $97^{\circ} 10^{\prime} \mathrm{W}$ Long).

\section{W-1372. Beadle County, South Dakota}

$12,200 \pm 400$

10,250 в.с.

$9820 \pm 300$

7870 в.C.

Wood from Beadle County, SW1/4 SW1/4 SW1/4 SW1/4 sec. 31, T 109 N, R $63 \mathrm{~W}\left(44^{\circ} 11^{\prime} 42^{\prime \prime} \mathrm{N}\right.$ Lat, $98^{\circ} 27^{\prime} 2^{\prime \prime} \mathrm{W}$ Long), South Dakota. From contact between unoxidized till and oxidized sand and gravel at depth of $41 \mathrm{ft}$. Coll. 1963 by L. S. Hedges and Robert Schoon; subm. by D. J. McGregor, South Dakota Geol. Survey, Vermillion. Comment (D.J.M.) : date corroborates W.80l ( $(12,000 \pm 400$, USGS V), and W.987 (12.530 \pm 350, USGS VII) and 
sugrgests that date obtained on W-983, which was apparently from same log as W.987, is anomalous $(10,350 \pm 300$, USGS VII $)$.

\section{W-1374. James River Dam, South Dakota}

$>32,000$

Peat from carbonaceous zone in hank cut in James River Diversion Dam, SEl/1. SE $1 / 4 . \mathrm{SW} 1 / 4 \mathrm{NW} 1 / 4$ sec. $13, \mathrm{~T} 113 \mathrm{~N}, \mathrm{R} 62 \mathrm{~W}\left(44^{\circ} 35^{\prime} 51^{\prime \prime} \mathrm{N}\right.$ Lat, $98^{\circ}$ $14^{\prime} 8^{\prime \prime}$ W Long), Beadle County, South Dakota. Coll. 1963 by L. S. Hedges; subm. by D. J. McGregor. Comment (D.J.M.) : date indicates presence of at least early Wisconsin drift in central South Dakota.

\section{W-1373. Shue Creek valley, South Dakota $\quad 14,000 \pm 500$ 12,050 в.c.}

Pelecypod shells from lake clay, Shue Creek valley, NW1/ NW1/4 NE $1 / 1$ NE1/4 sec. $27, \mathrm{~T} 112 \mathrm{~N}, \mathrm{R} 60 \mathrm{~W}\left(44^{\circ} 29^{\prime} 4^{\prime \prime} \mathrm{N}\right.$ Lat, $98^{\circ} 1^{\prime} 3^{\prime \prime} \mathrm{W}$ Long). Bcadle County, South Dakota. Coll. 1963 by L. S. Hedges; suhm. by D). J. McGregor. Comment (D.J.M.) : dates a maximum of a late Wisconsin advance in central South Dakota.

\section{Hixton series, Wisconsin}

Wood and organic debris ca. $1 / 4$ mi S of Hixton, N1/2 SW $1 / 1$ Sl $1 / 1$ sece 17 , T $22 \mathrm{~N}, \mathrm{R} 5 \mathrm{~W}\left(44^{\circ} 23^{\prime} \mathrm{N}\right.$ Lat, $91^{\circ} 01^{\prime} \mathrm{W}$ Long), Jackson County, Wisconsin. From sedimentary sequence in a meander scar cut in a late Pleistocenc (Cary) terrace on $S$ side of Trempealeau Valley. Stratigraphy, top to bottom: diatomite. $6 \mathrm{in}$; organic debris (W-1392), 6 in.; sand with wood fragments (W-1391). Coll. 1963 and subm. by G. W. Andrews. Comment (G.W.A.) : these are first dates obtained on organic material in Pleistocene valley alluvium in this part of Driftless Area. Dales compare favorably with age of the classic Two Creeks localities in castern Wisconsin. They are maximum for the diatomite, which appears to be late 'Two Creeks or Valders.

W-1392. Organic debris

\section{W-1391. Wood}

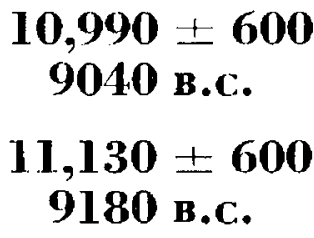

$>33,000$

Woody material from Marshfield, NW $1 / 4$ sec. $2, \mathrm{~T} 25 \mathrm{~N}, \mathrm{R} 3 \mathrm{E}\left(14^{\circ} 40^{\prime}\right.$
at. $90^{\circ} 10^{\prime} \mathrm{W}$ Long), Wood County, Wisconsin. Recovered from test well Y Lat, $90^{\circ} 10^{\prime} \mathrm{W}$ Long), Wood County, Wisconsin. Recovered from test well
from between 61 and $62 \mathrm{ft}$, in outwash sand. Coll. 1962 by Layne-Northwest Co.; subm. by C. L. R. Holt, Jr. Comment: a sample of disseminated humus in a proglacial lacustrine deposit coll. a few mi S of site in Wood County dated $>15,000$ (Nuclear Science and Engineering Corp., no number). These dates indicate that north-central Wisconsin was glaciated prior to Farmdale lime, possilly in Early Wisconsin.

$$
\text { C. Western U.S. }
$$

\section{W-1428. Yuma Mesa, Arizona}


test well in Pleistocene sand and gravel. Coll. 1961 by F. J. Frank; subm. by C. C. McDonald.

\section{W-1321. Pinnacles area, California}

$$
\begin{aligned}
& 32,500 \pm 2000 \\
& 30,550 \text { в.C. }
\end{aligned}
$$

Tufa from S half of Searles Valley, near The Pinnacles $\left(35^{\circ} 36^{\prime} 45^{\prime \prime} \mathrm{N}\right.$ Lat, $117^{\circ} 22^{\prime} 15^{\prime \prime} \mathbb{W}$ Long), California. From middle of $10-\mathrm{ft}$ section of lake sand. Overlying two units of lake silt are believed correlative with the "Parting Mud" (Flint and Gale, 1958); unit sampled is correlated with either the lower part of the "Parting Mud" or the "Lower Salt" (23,000 to 34,000 yr old). Coll. 1963 and subm. by G. I. Smith. Comment (G.I.S.) : date fits one interpretation of the field relations. However, sample is apparently from same horizon as $\mathbb{W} \cdot 1323,13,700 \pm 350$ (this list), which conflicts. W-1323, however, is a tufa that has undergone solution and recrystallization, with possible contamination by younger carbon. On the other hand, W-1321 is close to many large pinnacles composed of much older carbonate, some of which may have been incorporated during recrystallization.

\section{W-1324. Salt Wells Canyon, California \\ $22,500 \pm 600$ 20,550 в.c.}

Tufa from near mouth of Salt Wells (Poison) Canyon along W edge of Searles Valley, SE corner of sec. 14, T $26 \mathrm{~S}, \mathrm{R} 2 \mathrm{E}\left(35^{\circ} 40^{\prime} 30^{\prime \prime} \mathrm{N}\right.$ Lat, $117^{\circ}$ $25^{\prime} 20^{\prime \prime} \mathrm{W}$ Long), California. Tufa layer occurs $2 \mathrm{ft}$ below top of white-silt unit $7 \mathrm{ft}$ thick, correlated with middle part of lowest of three lacustrine units separated by erosional unconformities. Coll. 1963 and subm. by G. I. Smith. Comment (G.I.S.) : date is compatible with one interpretation of the correlation between these units and the subsurface units in Searles Lake, but more likely one date is too young, as suggested by a slightly older date on mollusks from this horizon (W.1422, this list).

\section{W-1327. Salt Wells Valley, California}

$$
\begin{aligned}
& 11,730 \pm 350 \\
& 9780 \text { в.с. }
\end{aligned}
$$

Oölites from $\mathrm{E}$ and of Salt Wells Valley, $100 \mathrm{ft} \mathrm{E}$ of $\mathrm{NW}$ corner of sec. 28,

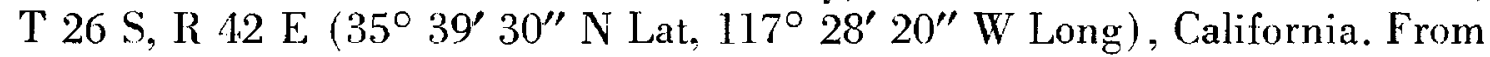
layer $1 \mathrm{ft}$ below top of prominent white lacustrine silt $3 \mathrm{ft}$ thick, overlain disconformably by lake gravel. Coll. 1962 and subm. by G. I. Smith. Comment (G.J.S.) : silt is probably one of youngest units in sequence of lake deposits, but stratigraphic position is uncertain.

\section{W-1322. San Bernardino County, California}

$$
\begin{gathered}
10,230 \pm 300 \\
\mathbf{8 2 8 0} \text { в.с. }
\end{gathered}
$$

Tufa from S edge of Searles Valley, San Bernardino County, SW1/4 NW1/4 sec. 12 , T 28 S, R 42 E ( $35^{\circ} 30^{\prime} 50^{\prime \prime} \mathrm{N}$ Lat, $117^{\circ} 25^{\prime} 00^{\prime \prime} \mathrm{W}$ Long), California. Tufa, somewhat weathered and recrystallized, is from $\mathrm{N}$-facing scarp of Garlock fault (Smith, 1960), alt $2200 \mathrm{ft}$, which formed during a high stand of Searles Lake. Coll. 1962 and subm. by G. I. Smith. Comment (G.I.S.) : on geologic evidence tufa is equivalent to "Bottom Mud" in Searles Lake, estimated to be early Wisconsin in age and to have extended from ca. 34,000 to over 100,000 yr ago. Date, therefore, seems in error, and may be due to incorporation of younger atmospheric carbon during weathering and recrystallization. 


\section{W-1323. Searles Valley, California}

$13,700 \pm 350$

11,750 в.с.

Tufa from $S$ half of Searles Valley, near The Pinnacles $\left(35^{\circ} 37^{\prime} 10^{\prime \prime} \mathrm{N}\right.$ Lat, $117^{\circ} 22^{\prime} 00^{\prime \prime} \mathrm{W}$ Long), California, from base of tufa lens in bar gravel $6 \mathrm{ft}$ thick where exposed on $\mathrm{E}$ side of Teagle $\mathbb{W}$ ash. Tufa, which has undergone solution and recrystallization by ground water, underlies two bodies of lake sediment believed equivalent to either the upper part or all of the "Parting Mud" in Searles Lake. Coll. 1963 and subm. by G. I. Smith. Comment (G.I.S.): age is probably too young, as age based on correlation with dated subsurface section in Searles Lake would be between ca. 18,000 and 34,000 yr.

\section{Searles Valley series, California}

Algal tufa, and organic residue from tufa, from SW Searles Valley, 2000 ft SE of SE corner of sec. 13 , T $27 \mathrm{~S}, \mathrm{R} 42 \mathrm{E}\left(35^{\circ} 34^{\prime} 50^{\prime \prime} \mathrm{N} \mathrm{Lat}, 117^{\circ} 23^{\prime} 50^{\prime \prime}\right.$ W Long). California. Sample, little recrystallized. from tufa column, ca. $1 \mathrm{ft}$ high, at base of silt section beneath lake bar. Silt and bar gravel belong to lower of two lake units correlated with upper part or all the "Parting Mud" in Searles Lake. Coll. 1963 and subm. by G. 1. Smith. Comment (C.I.S.) : dates agree with that of $\left.\mathrm{W}_{-}\right] 325$ (this date list) on tufa from same horizon $6 \mathrm{mi}$ to the E.

\section{W-1318. Tufa}

W-1418. Organic residue
$12,200 \pm 450$ 10,250 в.c.

$11,720 \pm 500$ 9770 в.c.

$12,000 \pm 400$ 10,050 в.c.

\section{W-1317. Southeast Searles Valley, California}

Tufa from SE comer of Searles Valley, (a. $1400 \mathrm{ft} \mathrm{S} 16^{\circ} \mathrm{E}$ of SE corner T 26 S. R 43 E $\left(35^{\circ} 35^{\prime} 10^{\prime \prime} \mathrm{N} \mathrm{Lat,} 117^{\circ} 16^{\prime} 50^{\prime \prime} \mathrm{W}\right.$ Long), California. At base of $30-\mathrm{ft}$ sec. of lake sand and silt and alluvial gravel. In this part of valley, unit is uppermost in local series of lake sediments, but is tentatively correlated with units in other parts of basin that are overlain by two younger series of lake sediments. Coll. 1962 and subm. by G. I. Smith. Comment (G.I.S.) : date younger than expected from field relations. Field correlation of this unit with lower part of "Parting Mud" or "Lower Salt." age should be between ca. 18,000 and $34,000 \mathrm{yr}$.

\section{W-1325. Southern Searles Valley, California $\quad 12,110 \pm 300$}

Tufa from S Searles Valley ca. $1100 \mathrm{ft} S 23^{\circ} \mathrm{W}$ of sec. corner marking SE corner of T $26 \mathrm{~S}, \mathrm{R} 43 \mathrm{E}$ ( $35^{\circ} 36^{\prime} 40^{\prime \prime} \mathrm{N}$ Lat. $117^{\circ} 17^{\prime} 50^{\prime \prime} \mathrm{W}$ Long), California, from hase of bar gravel $2 \mathrm{ft}$ thick, continuous with that from which W-1318 was coll. (sce this date list). Coll. 1962 and subm. by G. I. Smith. Comment (G.I.S.) : date agrees with that on tufa and its organic residue coll. from same horizon $6 \mathrm{mi} W(\mathbb{W}-1318$ and $W-1418$, this date list).

\section{$\begin{array}{ll}\text { W-1422. Western Searles Valley, California } & \mathbf{2 7 , 4 0 0} \pm \mathbf{8 0 0} \\ & \mathbf{2 5 , 4 5 0} \text { в.c. }\end{array}$}

Mollusk shells from W edge of Searles Valley, $500 \mathrm{ft}$ W of SE corner, 
sec. 24, T 26 S. R 42 E (35 $39^{\prime} 40^{\prime \prime}$ N Lat, $117^{\circ} 24^{\prime} 20^{\prime \prime}$ W Long), California. from contact zone (ca. $3 \mathrm{ft}$ thick) between sand and silt in middle of lowest of three lacustrine units separated by unconformities. Coll. 1963 and suhm. hy G. I. Smith. Comment (C.I.S.) : sampled zone thought equivalent to upper part of "Bottom Mud" in Searles Lake (top: ca. 34,000 yr; base > 100,000 yr). Contamination by young carbon may be responsible for discrepancy. Possibly. however, correlative is "Lower Salt" in Searles Lake (ca. 24,000 to 34,000 yr), a better fit.

\section{East Mesa series, California}

Samples of ground water from test wells drilled on eastern edge and SE corner of East Mesa, Imperial County, California, in Pleistocene sand and gravel of the Colorado River delta. Coll. 1964 by J. H. Robison; subm. by Burdge Irelan. Comment (B.I.) : dates of W-1419 and W-142I (fresh water samples, ca. $800 \mathrm{ppm}$ dissolved solids) help determinate rate of ground-water movement from Colorado River to Imperial Valley. W-1419 was ca. 10\% contaminated with leakage from a canal; assuming contaminating water was of zero age, adjusted age of the sample would be ca. $2800 \pm 1,00$. W-14,20 consists of hrackish water containing $1960 \mathrm{ppm}$ dissolved solids.

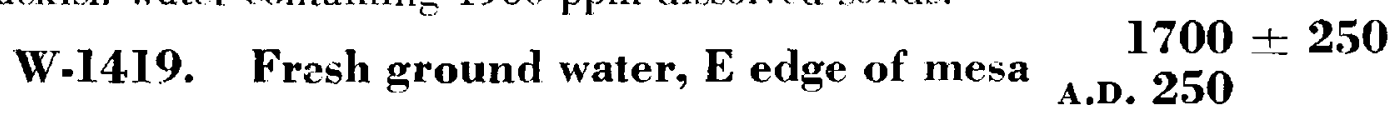

Sample from E edge of East Mesa, NW $/ 4$ sec. 12, T 16 S, R 19 E $\left(32^{\circ}\right.$ $46^{\prime} 46^{\prime \prime} \mathrm{N}$ Lat, $114^{\circ} 59^{\prime} 15^{\prime \prime} \mathrm{W}$ Long .

\section{W-1420. Brackish ground water}

$25,000 \pm 800$ 23,050 в.C.

Sample from E edge of East Mesa, SW $1 / 4$ sec. 15, T 15 S, R 18 E $\left(32^{\circ}\right.$ $50^{\prime} 47^{\prime \prime} \mathrm{N}$ Lat, $115^{\circ} 6^{\prime} 17^{\prime \prime} \mathrm{W}$ Long).

\section{W-1421. Fresh ground water, SE corner of $\quad 1820 \pm 250$ mesa \\ A.D. 130}

Sample from SE corner of East Mesa, SE $1 / 4$ sec. 31 . T 16 S, R 20 E $132^{\circ}$ $42^{\prime} 49^{\prime \prime} \mathrm{N}$ Lat, $114^{\circ} 56^{\prime} 27^{\prime \prime} \mathrm{W}$ Long).

\section{Santa Ana Gap series, California}

Peat from $3 \mathrm{mi} E$ of Huntington Beach, NE $1 / 4$ NE $1 / 1$ sec, 6 , T $6 \mathrm{~S}, \mathrm{R} 10$ W (33 $40^{\prime} \mathrm{N}$ Lat, $117^{\circ} 57^{\prime} 14^{\prime \prime}$ W Long), Orange County, California. Samples in flat-bedded fine-grained sediments of Recent age in upper division of Recent deposits, overlying the Talbert water-bearing zone. Coll. 1962 by Gilbert Torres and K. H. Wiebe; subm. by J. F. Poland. Comment (J.F.P.) : upper division of Recent deposits, 50 to $80 \mathrm{ft}$ thick, was laid down on lower division (Talbert water-bearing zonc) during post-Pleistocene backfilling of canyon cut in Pleistocene time. Dates obtained for 36 - to $10 \mathrm{ft}$ depth are in reasonable agreement with Curray's curve for late Quaternary sealevel (Curray, 1961). 


\section{W-1407. Peat at 39.5 to $40.5 \mathrm{ft}$}

$8030 \pm 300$

6080 в.c.

Dark reddish-brown clayey peat 39.5 to 10.5 ft below surface.

\section{W-1413. Scott Creek, California}

$>32,000$

Detrital charcoal in alluvium from sea-cliff exposure at mouth of Scott Creck. Santa Cruz County $\left(37^{\circ} 02^{\prime} 30^{\prime \prime} \mathrm{N}\right.$ Lat, $122^{\circ} 13^{\prime} 45^{\prime \prime} \mathrm{W}$ Tong), California. Stratioraphy of stream terrace, top to bottom: clean sand, prohably colian: alluvium 4 to $11 \mathrm{ft}$, with charcoal hedrock. Coll. 1963 and subm. by W. C. Bradley. Comment (W.C.B.) : stream terrace is younger than lowest prominent marine terrace, which is $>39,000 \mathrm{yr}$ old (Bradley, 1956); hence charcoal date is consistent.

\section{W-1376. Ano Nuevo Creek, California}

\section{$10,200 \pm 300$ 8250 в.c.}

Detrital wood fragments from alluvial fill in valley of Ano Nuevo Creek, exposed in s:a cliff at mouth of modern Ano Nuevo Creek $\left(37^{\circ} 07^{\prime} 00^{\prime \prime} \mathrm{N}\right.$ Lat, $122^{\circ} 18^{\prime} 20^{\prime \prime} \mathrm{W}$ Long), California. Coll. 1962 and subm. by W. C. Bradley, Lniv. of Colorado, Boulder. Comment: alluvium is younger than the marine terrace adjacent to the valley, but older than the sea cliff. Apparently alluviation resulted from faulting, rather than from rise of sealevel.

\section{W-1408. Ano Nuevo Point, California \\ $2800 \pm 300$ \\ 850 в.c.}

Roots of willow tree from sea cliff on $\mathbb{N}$ side of Ano Nuevo Point, San Mateo County $\left(37^{\circ} 7^{\prime} 45^{\prime \prime} \mathrm{N}\right.$ Lat, $122^{\circ} 20^{\prime} 12^{\prime \prime} \mathrm{W}$ Long), central California coast. Sample is from middle of peat layer overlain and underlain by dune sand. Entire siction overlies mature soil in sediments of lowest prominent marine terrace of the area. Coll. 1962 by R. R. Curry; subm. by W. C. Bradley. Comment (W.C.B.) : marine terrace was exposed long enough for a mature soil to form on its deposits, and was finally invaded by sand dunes. Stratigraphy of dune sand suggests two main periods of dune activity separated by a period of dune stability. Date indicates period of dune stability ca. $2800 \mathrm{yr}$, and that the period of youngest dune activity has occured since then.

\section{W-1417. Laguna Creek, California}

$$
\begin{array}{r}
1440 \pm 250 \\
\text { A.D. } 510
\end{array}
$$

Detrital-charcoal fragments, mouth of intermittent stream $\mathrm{N}$ of mouth of Laguna Creek, 2 mi SE of Davenport, Santa Cruz County $\left(36^{\circ} 59^{\prime} 00^{\prime \prime} \mathrm{N}\right.$ Lat. $122^{\circ} 9^{\prime} 20^{\prime \prime} \mathrm{W}$ Long), California. Sample occurs in gravolly alluvium interbedded with beach or dune sand. Coll. 1963 and subm. by W. C. Bradley. Comment (W.C.B.) : alluvium occupies valloy cut below lowest prominent marine terrace. Alluvium from Scott Creek, 5 to $6 \mathrm{mi} \mathrm{NW}$, dates $>32,000$ B.P. (W-1113, this list).

\section{Swan Lake series, Idaho}

Peaty material from core in $\mathrm{S}$ side of Swan Lake, 1 mi $\mathrm{S}$ of hamlet of Swan I ake. W $\mathrm{I} / 2$ ser. 14, T $13 \mathrm{~S}$, R $38 \mathrm{E}$ Bannock County (42 $17^{\prime} \mathrm{N}$ Lat. 
381 Betsy Levin, Patricia C. Ives. Charles L. Oman and Meyer Rubin

$112^{\circ} 01^{\prime}$ W Long), Idaho. Core pollen analyzed hy R. C. Bright, Limnological Center. U. of Minn. Coll. 1962 and subm. hy R. C. Bright and H. E. Wright, Jr.

W-1340. 174-180 cm depth

$1850 \pm 200$
A.D. 100

Black peaty clay from 2 -in. core composed mostly of fragments of Typha latifolia; dates a large grass peak and pine peak in a pollen diagram.

W-1339. 585-595 cm depth

$10,190 \pm 250$

8240 в.C.

Dark brown peaty copropel, peat mostly of Typha latifolia; dates significant decrease of pine in pollen diagram and increase of Artemisia, chenopods. grasses, and Ambrosia. Tentatively thought to date glacial-postglacial boundary.

\section{W-1338. 795-805 $\mathrm{cm}$ depth}

$12,090 \pm 300$ 10,140 в.с.

Typha latifolia; date defines time of formation of Swan I.ake. Since Swan Lake is in outlet channel of Iake Bonneville, date is also maximum for withdrawal of Lake Bonneville from Provo level, not reoccupied thereafter.

\section{W-1366. Keaster Kill, Montana}

$1945 \pm 250$

Charcoal from archeol. site, NE $1 / 4$ SW $1 / 1$ SE $1 / 4$ sec. 15 , T $24 \mathrm{~N}, \mathrm{R} 22 \mathrm{E}$ $\left(77^{\circ} 51^{\prime} 10^{\prime \prime} \mathrm{N}\right.$ Lat, $108^{\circ} 52^{\prime} 45^{\prime \prime} \mathrm{W}$ Long $)$, Phillips County, Montana; $11.5 \mathrm{ft}$ below floor of a deep coulee. Coulee was deeper when used as a bison kill. Coll. 1963 and subm. by L. B. Davis, Northern Montana College, Havre, Comment: obsidian point found near sample was dated by the hydration method at 960 to $1400 \mathrm{yr}$ B.P.

\section{W-1416. Sun River Canyon, Montana}

$4740 \pm 250$ 2790 в.C.

Snail shells from Sun River Canyon, NE1/4 SEL/4 sec. 27 , T $21 \mathrm{~N}, \mathrm{R} 7 \mathrm{~W}$ $\left(47^{\circ} 32^{\prime} 42^{\prime \prime} \mathrm{N}\right.$ Lat, $122^{\circ} 28^{\prime} 55^{\prime \prime} \mathrm{W}$ Long), Montana. From top of lake silt and clay with an ash bed. Coll. 1963 and subm. by M. R. Mudge. Comment (M.R.M.) : snails from beneath ash dated $7870 \pm 200$ (W.765, USGS V). The two dates then bracket the ash, determined to fre Calata ash lyy ehemical and quantitative spectrographic analyses.

\section{Winnemucca series, Nevada}

Clam shells (Anodonta) from longshore hars of Lake Lahontan, near Winnemucea $\left(41^{\circ} 00^{\prime} \mathrm{N}\right.$ Lat, $117^{\circ} 45^{\prime} \mathrm{W}$ Long), Nevada. Coll. 1960 and subm. by K. Cartwright, Illinois Geol. Survey, Urbana. Comment (K.C.) : samples immediately antedate last emergence. Dates agree with those obtained on upper unit of Lake Bonneville: Group.

\section{W-1050. Gravel pit, $S$ side}

$13,350 \pm 400$ 11,400 в.c.

Shells from $S$ side of Western Pacific R. R. gravel pit, NE $1 / 4$ SW $1 / 1$ $\mathrm{NW} 1 / 4$, sec. $25 . T 36 \mathrm{~N}, \mathrm{R} 37 \mathrm{E}$, alt $1323 \mathrm{ft}$, in Lahontan bar gravel overlain lyy Lahontan silt. 


\section{W.1052. Gravel pit, $\mathbf{N}$ side}

$12,700 \pm 400$

10,750 B.c.

Shells from 100 yd N of W-1050; same stratigraphy.

W-1051. Winnemucca

$13,200 \pm 400$

11,250 в.с.

Sample from lacustrine silt between two gravel layers, SW1/4 NW1/4 SE $1 / 4$, sec. 19 , T $36 \mathrm{~N}$, R $38 \mathrm{E}$.

\section{W-1328. Santa Fe, New Mexico}

$\mathbf{2 8 0 0} \pm \mathbf{2 5 0}$

850 в.c.

Charcoal and wood in alluvial fill of Coyote C Arroyo, ca. $9.2 \mathrm{mi} \mathrm{NW}$ of Santa Fe, SE $1 / 4$ sec. 30 , T 18 N, R 9 E $\left(35^{\circ} 45^{\prime} 30^{\prime \prime} \mathrm{N}\right.$ Lat, $106^{\circ} 01^{\prime} 30^{\prime \prime} \mathrm{W}$ Long), New Mexico. Sample, thought to be tree stump or log burned by lightning or other natural fire event, coll. $4 \mathrm{ft}$ above base of 6.5 - $\mathrm{ft}$ alluvial fill in silt with cobbles. Coll. 1963 by L. B. Leopold; subm. by W. W. Emmett. Comment (W.W.E.) : date confirms hypothesis on sequence of alluviation and erosion in the area and compares with date $(2620 \pm 200 \mathrm{yr}$; W.819, USGS V) obtained on charcoal from Fillmore Arroyo (Ruhe, 1962).

W-1398. Abert Lake, Oregon

A.D. 1700

$\mathbf{2 5 0} \pm \mathbf{2 0 0}$

Stump (Juniperus occidentalis) from SE shore of Abert Lake, 6 mi NE of Valley Falls $\left(12^{\circ} 33^{\prime} \mathrm{N}\right.$ Lat, $120^{\circ} 13^{\prime} \mathrm{W}$ Long), Oregon. Stump in place, hase at alt $4260 \mathrm{ft}$. Coll. 1962 and subm. by K. N. Phillips. Comment (K.N.P.) : tree grew when lake was continuously below alt $4,260 \mathrm{ft}$.

\section{W-1291. Mosier, Oregon}

$<\mathbf{2 0 0}$

Wood chip from gravel quarry near $\mathrm{SE}$ corner $\mathrm{NWL} / 4 \mathrm{SE} 1 / 4$ sec. $1, \mathrm{~T} 2 \mathrm{~N}$, R $11 \mathrm{E}, 1 / 2 \mathrm{mi} \mathrm{E}$ of Mosier $\left(45^{\circ} 40^{\prime} \mathrm{N}\right.$ Lat, $121^{\circ} 22^{\prime} \mathrm{W}$ Long), Oregon. Coll. 1962 and subm. by R. C. Newcomb. Comment: sample expected to date Lake Lewis outwash (late Wisconsin?), but age suggests intrusion.

\section{W-1359. Thorne Cave, Utah}

$4170 \pm 250$ 2220 в.C.

Charcoal from alcove in Navajo Sandstone, E side of Cliff Creek, $4 \mathrm{mi} \mathrm{E}$ of Jensen, Uintah County, NW $1 / 4$ SW $1 / 4$ sec. 19 , T $5 \mathrm{~N}, \mathrm{R} 24 \mathrm{E}\left(10^{\circ} 22^{\prime} \mathrm{N}\right.$ Lat, $109^{\circ} 16^{\prime} \mathrm{W}$ Long), Utah, from lowest habitation layer in Thorne Cave. Sterile red alluvium in bottom of cave is overlain by $12 \mathrm{ft}$ of water-laid sand containing charcoal from campfires, and other signs of human occupation. Culture includes food-bone scrap, bone awls, fragments of slab basin metates, manos, a twilled basketry impression in gilsonite, stemmed lanceolate point, small choppers and scrapers, and a scapula shredder or seed-gathering sickle, representing some variant of the Desert Culture ( Jennings and Norbeck, 1955). Human occupation occurred during accumulation of at least $90 \mathrm{ft}$ of alluvium in valley of Cliff Creek, which eventually sealed the cave. Alluvium merges with the 35-ft terrace of Green River at Jensen, aparently post-Altithermal. Coll. 1963 by J. D. Jennings and K. Day; subm. by H. E. Malde. Comment (J.D.J.) : date agrees with previous date from Level 7 (M-783; $4230 \pm 250$ ). 


\section{W-1227. Capitol Hill, Seattle, Washington}

Wood fragment in nonglacial silt and sand overlain by proglacial clay of Lawton Clay Member of Vashon Drift, W flank of Capitol Hill, ca. $115 \mathrm{ft}$ alt, Seattle ( $47^{\circ} 38^{\prime} \mathrm{N}$ Lat, $122^{\circ} 19^{\prime} \mathbb{W}$ Long), Washington. Coll. 1962 by D. S. Tillson; subm. by D. R. Mullineaux. Comment (D.R.M.) : this is youngest date from this nonglacial interval. Other Seattle dates ca. 20,000 to 24,000 yr (W-1091, W-1182, USGS VII; Dorn and others, 1962), and dates from this interval in other parts of the Puget Sound.Georgia Strait range from 24,000 to more than 40,000 yr. Two dates from bottom of Lake Washington indicate Vashon ice retreated from Seattle area by $14,000 \mathrm{yr}$ ago; this date suggests, therefore, that glacier advanced into and retreated from S part of lowland very rapidly.

\section{W-1305. Eastlake Avenue, Seattle, Washington $\quad 15,100 \pm 600$ 13,150 в.c.}

Fragments of wood from freeway cut just $\mathrm{E}$ of Eastlake Arenue, Seattle $\left(47^{\circ} 37^{\prime} 30^{\prime \prime} \mathrm{N}\right.$ Lat, $122^{\circ} 19^{\prime} 30^{\prime \prime} \mathrm{W}$ Long), Washington, from weathered sediments, containing thin peat layers, deposited during an interglacial episode. These nonglacial sediments overlie pre-Vashon Drift and underlie Lawton Clay Member of Vashon Drift. Coll. 1963 and subm. by H. H. Waldron; interpreted by D. R. Mullineaux. Comment: date is similar to W-1227 (this list). The two are the youngest known to antedate Vashon glacial advance, and indicate that adrance occurred several thousand yr later than previously believed. In conjunction with dates of ca. 13,000 to $14,000 \mathrm{yr}$ for material on top of Vashon Drift (Mullineaux, Waldron, and Rubin, 1965), these samples show that glaciation in Seattle area was very short.

W-1429. Hazelwood Tunnel, Seattle, Washington $>\mathbf{3 8 , 0 0 0}$

Wood fragment from Hazeluood tunnel, 1704. $\mathrm{ft} \mathrm{N}$ of $\mathrm{S}$ portal, Seattle ( $47^{\circ} 33^{\prime} \mathrm{N}$ Lat, $122^{\circ} 12^{\prime} \mathrm{W}$ Long), Washington, from probable nonglacial al. luvium underneath pre.Vashon drift. Coll. 1963 by E. R. McMaster; subm. by D. R. Mullineaux. Comment (D.R.M.) : overlying drift was apparently deposited during major pre-Vashon glaciation. Drift is possibly middle Wisconsin.

\section{Huckleberry Park series, Washington}

Coniferous wood stems from Huckleberry Park, Mt. Rainier Natl. Park (46 $55^{\circ} \mathrm{N} \mathrm{Lat,} 121^{\circ} 38^{\prime} \mathrm{W}$ Long), Washington. Stratigraphy, from top to bottom: 4 in. of peat and lithic ash; Layer W; 2 to 4 in. of peat and lithic ash; reworked pumice from Layer $C(\mathbb{W}-1397)$; Layer $C ; 6$ to 8 in. of gray lithic sand (W.1396 taken 2 in. below top of this bed). Coll. 1963 and subm. by D. R. Mullineaux. Comment (D.R.M.) : date of W-1396 agrees very well with that of W-1394. (this list) as upper limit for age of Layer C. W-1397 shows age of Layer C is not close to $550 \mathrm{yr}$ (Hopson and others, 1962) and that the moraine overlain by Layer $\mathrm{C}$ and younger than Layer $\mathrm{Y}$ is early Neoglacial (see W-1393, this list).

W-1397. Wood above Layer C

$$
\begin{array}{r}
1500 \\
\text { A.D. } 450
\end{array}
$$




\section{W-1396. Wood below Layer C}

$2340 \pm 200$
390 B.

\section{W-1437. Southworth, Washington}

$34,000 \pm 800$

32,050 в.c.

Peat from beach cliff along Colvas Passage, NE 1/4 sec. 11, T 24 N, R 2 E ( $47^{\circ} 40^{\prime} 35^{\prime \prime} \mathrm{N}$ Lat, $122^{\circ} 30^{\prime} 25^{\prime \prime} \mathrm{W}$ Long), Bremerton E quad, Washington. In fluvial and lacustrine silt, sand, and gravel overlain by Vashon Drift. Coll. 1963 and subm. by H. H. Waldron and D. R. Crandell. Comment (H.H.W. ): peat layer was formed during Olympia Interglaciation $(>38,000$ to ca. 15,000 yr ago) in the S Puget Sound lowland (Armstrong and others, in press).

\section{W-1458. Eglon, Washington}

Wood from beach bluff $1 \mathrm{mi} \mathrm{S}$ of Eglon, SW $1 / 4$ NE $1 / 4$ sec. 11, T $27 \mathrm{~N}, \mathrm{R} 2$ $\mathrm{E}\left(47^{\circ} 50^{\prime} 50^{\prime \prime} \mathrm{N}\right.$ Lat, $122^{\circ} 30^{\prime} 20^{\prime \prime} \mathrm{W}$ Long), Washington. From nonglacial deposit beneath Vashon Drift and above till of next-older glaciation. Nonglacial deposit included in the Kitsap Formation (Armstrong and others, in press). Coll. 1964 and subm. by D. R. Crandell and H. H. Waldron. Comment (D.R.C.) : deposit containing wood probably formed during early part of last major interglaciation, previously dated between ca. 15,000 and ca. 35,000 yr ago.

\section{W-1459. University Point, $W$ ashington}

Peat from beach bluff at Lniversity Point, W side of Port Orchard SW $1 / 4$ $\mathrm{SEl} / 4$ sec. 19, T $25 \mathrm{~N}, \mathrm{R} 2 \mathrm{E}$. Kitsap County $\left(47^{\circ} 38^{\prime} 20^{\prime \prime} \mathrm{N}\right.$ Lat, $122^{\circ} 35^{\prime} 30^{\prime \prime}$ W Long), Washington. From uppermost of two peat beds, interbedded with silt and clay, that lies within oxidized nonglacial sand and gravel of Olympic Mts. provenance. Coll. 1963 and subm. by D. R. Crandell and H. H. Waldron. Com. ment (D.R.C.) : sediments are regarded as nonglacial lacustrine and fluvial, formed during last major interglaciation, previously dated between ca. 15,000 and ca. 35,000 yr ago.

W-951. MeNeely Peak, Washington

$8750 \pm \mathbf{2 8 0}$

6800 B.C.

Fragments of carbonized wood from distinctive, widespread ash layer, older than Osceola Mudflow, from stream bank in cirque floor between McNeely Peak and Sourdough Mountain $\left(46^{\circ} 55^{\prime} \mathrm{N}\right.$ Lat, $121^{\circ} 38^{\prime} \mathrm{W}$ Long), Mt. Rainier Natl. Park, Washington. Coll. 1960 by D. R. Crandell and R. D. Miller; subm. by D. R. Crandell. Comment (D.R.C.) : date indicates cirque was free of Wisconsin-age ice before deposition of ash, and has not been reoccupied by glaciers in postglacial time.

\section{Mystic Lake series, Washington}

Coniferous wood stems $1 / 4$ mi $\mathrm{N}$ of Mystic Lake, Mt. Rainier Natl. Park ( $46^{\circ} 55^{\prime} \mathrm{N}$ Lat, $121^{\circ} 45^{\prime} \mathrm{W}$ Long), Washington, from interbedded pumice, lithic ash, and peat. Stratigraphy, top to bottom: 8 in. of peat; Layer W; 4 to 6 in. of peat (W-1393 at base); Layer $\mathrm{C} ; 4$ in. of lithic sand, probably ash (W.1394 at base) ; Layer $P$, thin silicic volcanic ash; layer of lithic sand and thin gray ash; and Layer Y (age ca. $3000 \mathrm{yr}$ ). Coll. 1963 and subm. by D. R. 
Mullineaux. Comment (D.R.M.): samples date Layer C as 2000 to $2400 \mathrm{yr}$ B.P., previously thought ca. $550 \mathrm{yr}$ (Hopson and others, 1962) or "more than $1000 \mathrm{yr}$ " (Crandell and others, 1962); and dates Layer P as $>2400 \mathrm{yr}$. Presence of Layer $\mathrm{C}$ and absence of Layer $\mathrm{Y}$ on Recent moraines indicates they are early Neoglacial.

W-1393. Wood above Layer C

W-1394. Wood above Layer $\mathbf{P}$
$2040 \pm 200$

90 в.c.

$2460 \pm 200$ 510 в.c.

$24,300 \pm 700$

22,350 в.c.
$7^{\circ} 36^{\prime}$ N Lat, $122^{\circ}$

\section{W-1388. Seattle, Washington}

Wood fragments from $N$ end of Beacon Hill, Seattle $\left(47^{\circ} 36^{\prime} \mathrm{N}\right.$ Lat, $122^{\circ}$
W Long), Washington. From zone 6 to 12 in. below top of 4 -ft layer of peat that crops out in a landslide scarp. Peat is below the Lawton formation and above varved clay. Coll. 1963 and subm. by D. R. Mullineaux. Comment (D.R.M.) : shows peat layer belongs to interglaciation immediately preceding Vashon Stade, rather than to an older interglaciation. Varved clay beneath peat is, therefore, equivalent to varved clay 1 to $2 \mathrm{mi}$ farther $\mathrm{N}$.

W-1061. Brush Creek, Wyoming

$$
\begin{array}{r}
1520 \\
\text { A.D. } 430
\end{array}
$$

Snail shells (Oreohelix subrudis) from fill in Brush Creek drainage, SW of Wheatland, in C SW $1 / 4 \mathrm{sec}$. 3, T $21 \mathrm{~N}, \mathrm{R} 69 \mathrm{~W}\left(41^{\circ} 48^{\prime} \mathrm{N}\right.$ Lat, $105^{\circ} 08^{\prime}$ W Long), Wyoming. Fill now being actively dissected, shells coming from upper part of eroded surface. Fill overlies the Hartville Formation. Coll. 1958 and subm. by L. S. McGrew. Comment (L.W.M.) : dates non-faulted alluvium older than present cycle of downcutting. Lnderlying faulted alluvium dated $9500 \pm 400$ (W-1060, USGS VII), indicating that faulting occurred between 1520 and 9500 yr ago.

\section{W-1386. Crowheart Butte, Wyoming \\ $11,100 \pm 300$ 9150 в.c.}

Travertine from Crowheart Butte area, Fremont County, NW1/4 sec. 9, T $40 \mathrm{~N}, \mathrm{R} 105 \mathrm{~W}\left(43^{\circ} 26^{\prime} 45^{\prime \prime} \mathrm{N}\right.$ Lat, $109^{\circ} 28^{\prime} 00^{\prime \prime} \mathrm{W}$ Long), Wyoming. Overlies Lenore terrace (Blackwelder, 1915) of Pinedale age. Coll. 1963 and subm. by J. F. Murphy. Comment (J.F.M.) : date is minimum for Pinedale in this area.

\section{Death Gulch series, Wyoming}

Wood from banks of Cache Creek near mouth of Death Gulch, Yellow. stone Natl. Park ( $44^{\circ} 49^{\prime} \mathrm{N}$ Lat, $110^{\circ} 07^{\prime}$ W Long), Wyoming. Coll. 1962 by R. O. Fournier and J. M. Good; subm. by R. O. Fournier. Comment (R.O.F.) : inclosing sediments had been thought to be outwash.

W.1284. Log, N bank

W.1\%g6. Log, S bank

$$
\begin{array}{r}
800 \\
\begin{array}{r}
\text { A.D. } 1150 \\
1560
\end{array} \pm 200 \\
\text { A.D. } 390
\end{array}
$$




\section{W-1364. Gibbon River Canyon, Wyoming}

$9440 \pm 300$

7490 в.c.

Carbonaceous tuff $200 \mathrm{yd} \mathrm{N}$ of right-angle bend in Gibbon River, $1.4 \mathrm{mi}$ $\mathrm{S}$ of Beryl Spring and $2.3 \mathrm{mi} \mathrm{N}$ of Gibbon Falls, Yellowstone Park $\left(44^{\circ} 59^{\prime} \mathrm{N}\right.$ Lat, $110^{\circ} 42^{\prime} \mathrm{W}$ Long), Wyoming. Tuff is probably from a local source. Coll. 1963 by J. D. Love, J. Montagne, and J. M. Good; subm. by J. D. Love. Comment (J.D.L.) : tuff appears to be closely related to rhyolite of the Canyon.

\section{Grand Teton Park series, Wyoming}

Mollusk shells from mixed loess and sliderock, Grand Teton Park $\left(43^{\circ} 41^{\prime}\right.$ $\mathrm{N}$ Lat, $110^{\circ} 46^{\prime} \mathrm{W}$ Long), Teton County, Wyoming. From post-Bull Lake loess. faulted down $50 \mathrm{ft}$ or more, overlying Bull Lake gravel. Coll. 1961 and subm. by J. D. Love. Comment: dates interval between Bull Lake and Pinedale Glaciations (Love and Taylor, 1962).

W.1071. Shells, sec. 27

$15,300 \pm 500$ 13,350 в.с.

Shells from NW corner SW11/4 NW1/4 sec. 27, T 41 N, R 116 W.

W-1078. Shells, sec. 15

Shells from NE1/4 SE1/4 SW1/4 sec. 15, T 41 N, R 116 W.

$13,980 \pm 700$ 12,030 в.C.

\section{W-1273. Pilgrim Creek, Wyoming}

Carbon from $\mathrm{S}$ face of high spur overlooking junction of two forks of Pilgrim Creek to E, Teton County, center NW1/4 NE1/4 sec. 29, T 46 N, R 114 W ( $43^{\circ} 56^{\prime} N^{\prime}$ Lat, $110^{\circ} 34^{\prime}$ W Long), Wyoming. Sample consists of sporadic chunks of carbon imbedded in sandy silt and sandstone. Coll. 1957 by J. D. Love and John Montagne; subm. by J. D. Love. Comment (J.D.L.) : W.312 (USGS IV), dated at $27,100 \pm 800 \mathrm{yr}$, is from same horizon, although $\mathrm{W} \cdot 1273$ coll. from farther below surface. No obvious explanation for discrepancy.

\section{W-1244. Tosi Creek, Wyoming}

$7670 \pm 350$

5720 в.c.

Mollusk shells $0.4 \mathrm{mi}$ S of Tosi Creek, NW1/4 sec. 35 , T $39 \mathrm{~N}, \mathrm{R} 110 \mathrm{~W}$, Sublette County $\left(43^{\circ} 18^{\prime} \mathrm{N}\right.$ Lat, $110^{\circ} 00^{\prime} \mathrm{W}$ Long), Wyoming, imbedded in marl apparently deposited against Pinedale lateral moraine. Coll. 1959 and subm. by J. D. Love. Comment (J.D.L.) : date measures downcutting by Green River since deposition of marl.

\section{Bill Dew Ranchseries, Wyoming}

Organic material from core taken from lake $1 \mathrm{mi} \mathrm{N}$ of Bill Dew ranch, $21 \mathrm{mi} \mathrm{NNW}$ of Pinedale, Sublette County $\left(43^{\circ} 31^{\prime} \mathrm{N}\right.$ Lat, $110^{\circ} 01^{\prime} \mathrm{W}$ Long). Wyoming. Core was pollen analyzed by R. C. Bright at Limnological Research Center, U. of Minn. Coll. 1962 and subm. by Bright.

\section{W-1299. 505-515 em depth}

Wood dates a birch peak in pollen diagram and a litter layer, and establishes rate of sedimentation in lake. 


\section{W-1301, 695-710 $\mathrm{cm}$ depth}

Organic rich clay with charophyte stem fragments; dates minor fluctuations in chenopod and grass curves in pollen diagram.

\section{W-1302. 822-830 cm}

Organic-rich clay with charophyte stems; dates increase of pine curve and decrease of sage, spruce, and birch curves in pollen diagram. Horizon thought to represent late glacial-postglacial houndary in the area, and end of the Pinedale Glaciation.

\section{W-1303. $917-927 \mathrm{~cm}$ depth}

Organic-rich clay with charophyte stems; dates decrease of pine and increase of birch, artemisia, spruce and fir in pollen diacram. Believed to indicate beginning of Pinedale Glaciation.

\section{W-1367. Tower Falls, Wyoming}

$3750 \pm 300$

$1800 \mathrm{~B}, \mathrm{C}$.

Carbonized wood in tuff $2800 \mathrm{ft}$ ENE of Tower Falls, Yellowstone Natl. Park (44 $56^{\prime} \mathrm{N}$ Lat, $110^{\circ} 25^{\prime} \mathrm{W}$ Tong), Wyoming. Coll, 1963 by J. M. Cood; subm, hy J. D. Love. Comment (J.D.L.) : ca. $700 \mathrm{ft}$ of lacustrine and lluvial deposits accumulated in canyon against Bull Lake ice, and were eroded out before deposition of strata from which W.1367 was coll. Relationships of Bull lake deposits and deposits which contained W-1367 indicale that Yellowstome Canyon is shallower now than it was during either episode of deposition.

\section{Alaska}

\section{W.1287. Bethel, Alaska}

Wood fragment from Well No. 2, U. S. Air Force Station, $5 \mathrm{mi}$ W of Bethel $\left(60^{\circ} 50^{\prime} \mathrm{N}\right.$ Lat, $161^{\circ} 55^{\prime} \mathrm{W}$ Long), Alaska. From sand at hase of permafrost at depth 603 to $605 \mathrm{ft}$ (alt $-430 \mathrm{ft}$ ) in deposits of Kuskokwim delta. Coll. 1962 and subm. by A. J. Feulner. Comment (A.J.F.) : date provides valuable reference point for lower part of Yukon-Kuskokwim deltaic section.

\section{W-1235. Imuruk Lake, Alaska}

$7400 \pm 300$ 5450 в.с.

Driftwood from partly slumped face of bluff cut in "Intermediate terrace" of Imuruk Lake terrace sequence of Hopkins (1959), SE shore of Shallow Bay, Imuruk Lake, Seward Peninsula (65 $38^{\prime} 40^{\prime \prime} \mathrm{N}$ Lat, $163^{\circ} 38^{\prime} 40^{\prime \prime} \mathrm{W}$ Long). Alaska. Stratigraphic sequence: terrace surface; peat in situ; ash; peat in situ; silt; detrital peat with blueberry, dwarf birch, and willow shrubs; slumped debris; basalt-pebble gravel with granitic-sand matrix; present lake level. Coll. 1961 and subm. by D. M. Hopkins. Comment (D.M.H.) : confirms age of W-1213, $9900 \pm 400$ (USGS VII), coll. in same terrace from $\mathrm{N}$ shore of Granite Bay. Both samples indicate faulting, which warped the "Intermediate" terrace" and shifted the outlet of Imuruk Lake, took place less than $10.000 \mathrm{yr}$ ago, and evidently as recently as $7400 \pm 300 \mathrm{yr}$ (Hopkins, 1963). 


\section{Lake George series, Alaska}

Alder wood from till in Lake George area SE of Palmer $\left(61^{\circ} 00^{\prime} \mathrm{N}\right.$ Lat, $118^{\circ} 30^{\prime} \mathrm{W}$ Long), Alaska, coll. at various stratigraphic positions beneath till units in terraced end moraines of Colony Glacier, recording recent glacial fluctuations. Coll. $196 \mathrm{I}$ and subm. hy Thor Karlstrom. Comment (T.K.) : samples coll. to determine whether the most recent complex of moraines in Lake George hasin included moraines of Tustumena as well as Tunnel age. Samples indicate that all moraines are of Tunnel age, and probably late Tunnel (since A.D. 1500). Thus during the more extensive and carlier Tunnel and Tustumena advances, Lake (Gorge Basin was probably completely filled with ice tributary to the extended Knik glacier. Apparently therefore Lake George basin formed during Tunnel II advance of the trunk Knik glacier that created an ice dam across mouth of the Lake George valley and that still persists. Glaciers tributary to Lake George valleys did not advance far enough in Tunnel II time to fill the valley, but built moraines in lake that still occupies ice-frec part of valley.

W-1313. Wood, Field No. 46A $<200$

W-1314. Wood, Field No. 46B $<200$

W-1315. Wood, Field No. 46C $\quad<200$

W-1326. Gilahina River, Alaska

$5250 \pm 300$

3300 в.с.

Spruce(?) wood from $5 \mathrm{mi}$ ENE of mouth of Gilahina River, Lower Chitina Valley, SE $1 / 4$, sec. 29 , T $5 \mathrm{~S}$, R $10 \mathrm{E}$, McCarthy B-8 quad. $\left(61^{\circ} 24^{\prime} 08^{\prime \prime}\right.$ V Lat, $113^{\circ} 38^{\prime} 40^{\prime \prime} \mathrm{W}$ Long), Alaska. From base of silty organic layer 3 to $8 \mathrm{ft}$ thick, overlying remnant of Wisconsin (?) lateral moraine. Coll. 1962 and sulm. hy Lynn A. Yehle. Comment (L.A.Y.) : date accords with W.1159, $(1300=300$, LSCS VII $)$ from base of surficial organic accumulation near axis of Chitina Valley.

\section{W-1337. West Fork, Gulkana River, Alaska}

$>38,000$

Wood fragments from N hank of W Fork of Gulkana River $\left(62^{\circ} 35^{\prime} 08^{\prime \prime}\right.$ N Lat, $145^{\circ} 50^{\prime}\left(02^{\prime \prime} \mathrm{W}\right.$ Long), Alaska, coll. from middle of 2 -ft unit of sand overlain hy fine gravel, sand, and diamicton. Coll. 1958 and subm. by O. J. Ferrians, Jr. and H. R. Schmoll. Comment (O.J.F.) : dates period, during last major glaciation, when extensive proglacial lake in Copper River Basin was higher than $2000 \mathrm{ft}$ (Ferrians and Schmoll, 1957).

\section{W-1343. Sanford, Alaska}

$28,300 \pm 1000$ 26,350 в.с.

Peat from $\mathrm{N}$ bank Sanford River $9 \mathrm{mi}$ upstream from its mouth, NE Copper River Basin (62 $16^{\prime} \mathrm{N}$ Lat, $144^{\circ} 58^{\prime} \mathrm{W}$ Long), Alaska. Coll. from top of 6-ft silty sand unit with peat, overlain by sand, gravel, and eolian sand. Coll. 1962 by H. R. Schmoll and subm. by O. J. Ferrians, Jr. Comment (0.J.F.): this sample and W-843 (31,300 \pm 1000 , USGS VI) from base of sampled unit bracket an interval during last major glaciation when proglacial lake in Copper River Basin (Ferrians and Schmoll, 1957) stood below $2150 \mathrm{ft}$. 
Absence of till stratigraphically above the dated horizon indicates glacier has not covered site since before 31,000 B.P.

\section{W-1379. Mentasta Basin, Alaska}

Wood and peat fragments from road cut on $\mathrm{E}$ side of Tok Cutoff section of Glenn Highway, Mile 77, Nabesna D-6 quad. (62 $52^{\prime}$ N Lat, $143^{\circ} 40^{\prime} \mathrm{W}$ Long), Alaska. Section includes silt and fine sand overlain by medium- to coarse sand with sampled matter $6 \mathrm{ft}$ below top. Coll. 1962 and subm. by H. R. Schmoll. Comment (H.R.S.) : date is an older minimum than given previously (I-364, >32,000, Isotopes III) and precludes corrclation with other $\mathrm{C}^{\mathrm{i} 1}$-dated deposits in adjacent areas, e.g. along Sanford hiver (W-843, 31,300 \pm 1000 , USGS V, and W.1343, 28,300 \pm 1000 , this list .

\section{W-1377. Ahtell Creek, Slana, Alaska}

$11,190 \pm 300$ 9240 в.C.

Peat and wood fragments in road cut on $E$ side of Tok Cutoff section of Glenn Highway, Mile 61.3, Nabesna C-6 quad. $162^{\circ} 43^{\prime} 24^{\prime \prime} \mathrm{N}$ Lat, $143^{\circ} 57^{\prime}$ $12^{\prime \prime}$ W Long), Alaska. Section from top: peat (Ahtell Creek Peat Bed; W-487, $9240 \pm 300$ was from top; W $429,11,440 \pm 300$, from base; USGS IV); coll. $45 \mathrm{ft} \mathrm{S}$; fine sand with organic layers (this sample from base of this unit); fine to medium sand; gravel. Coll. 1962 and subm. by Henry R. Schmoll. Comment (H.R.S.) : date agrees within statistics, with W-429.

W-1390. Lower Chitina Valley, Alaska

$>38,000$

Fragments of compressed wood from $9 \mathrm{mi}$ SW of McCarthy, S central part of McCarthy B-6 quad $\left(61^{\circ} 19^{\prime} 36^{\prime \prime} \mathrm{N}\right.$ Lat, $143^{\circ} 04^{\prime} 03^{\prime \prime} \mathrm{W}$ Long), Alaska, from thin organic-silt layer underlying clayey silt and overlying sandy gravel and diamicton. Coll. 1962 and subm. by Lynn A. Yehle. Comment (L.A.Y.) : an attempt to date till of last major glaciation, which formerly overlay this sequence.

\section{Middleton Island series, Alaska}

Driftwood coll. from various alts. on sea cliffs of Middleton Island to determine rate of uplift. First two samples coll. 1963 and subm. by George Plafker, second two coll. 1962 and subm. by Thor Karlstrom.

General Comment: samples of each pair are internally consistent, but together give a puzzling result.

\section{W-1404. Stage IV terrace}

$2390 \pm 200$ 440 в.C.

Driftwood from cliff $7000 \mathrm{ft} \mathrm{N}$ of SE tip of island, alt $38 \mathrm{ft}$, Middleton Island 1:250,000 quad. coordinates $(5.95,7.27) \quad 159^{\circ} 27^{\prime} \mathrm{N}$ Lat, $146^{\circ} 20^{\prime} \mathrm{W}$ Long), Alaska. Taken from beneath $4 \mathrm{ft}$ of peat on Stage IV Terrace, 4th highest of 5 terraces on island as mapped by D. J. Miller (1953). Dates time when terrace gravel was lifted above high water.

\section{W-1405. Stage I terrace}

Driftwood from sea cliff $3 \mathrm{mi}$ from $\mathrm{SW}$ tip of island at alt $99 \mathrm{ft}$, coordi- 
nates 5.8, 7.4 $\left(59^{\circ} 26^{\prime} \mathrm{N}\right.$ Lat, $146^{\circ} 22^{\prime} \mathrm{W}$ Long), Alaska, from beneath peat and above gravel of Stage I Terrace. Dates emergence.

\section{W-1259. Stage IV terrace}

$660 \pm 250$

Wood coll. from beach deposits on $\mathrm{E}$ side Middleton Island $\left(59^{\circ} 26^{\prime} \mathrm{N}\right.$ Lat, $146^{\circ} 20^{\prime}$ W Long), Alaska.

\section{W-1261. Stage IV terrace, upper sand}

W.1259 and W-1261 are associated with Miller's Terrace IV. Stratigraphy is as follows: turf; sand and gravel with driftwood (W-1261); organic silt; sand and gravel with driftwood (W-1259); glaciomarine beds exposed above high storm beach. Top of section 15 to $20 \mathrm{ft}$ above storm beach.

\section{W-1424. Gakona River, Alaska}

Peat from E bank of Gakona River ca. $20 \mathrm{mi}$ from its mouth $\left(62^{\circ} 30^{\prime} 00^{\prime \prime}\right.$ N Lat, $145^{\circ} 12^{\prime} 36^{\prime \prime}$ W Long), Alaska. Coll. from uppermost part of 1 - to 4 - $\mathrm{ft}$ layer of peat, silt, and sand, underlain and overlain by sand and gravel. Coll. 1955 and subm. by (O. J. Ferrians, Jr. and H. R. Schmoll. Comment (O.J.F.) : dates beginning of aggradation which occurred early in last major glaciation (Ferrians, 1963).

\section{W-1427. Iniakuk Lake, Alaska}

Wood fragments from bank of Iniakuk Lake outlet stream $1 / 3$ mi downstream from lake. south-central Brooks Ranges $\left(67^{\circ} 06^{\prime} \mathrm{N}\right.$ Lat, $153^{\circ} 10^{\prime} \mathrm{W}$ Long), Alaska. Taken from $13 \mathrm{ft}$ below surface of fluvial sand and gravel washed against terminal moraine of late Wisconsin age by ice-marginal drainage early in deglaciation. Moraines are tentatively correlated with the Echooka River Glaciation (Detterman et al., 1958) along $\mathrm{N}$ flank of Brooks Range, and dated as slightly earlier than 7500 B.P. (Porter, 1964). Coll. 1963 and subm. by T. D. Hamilton, Univ. of Wisconsin. Madison. Comment (T.D.H.) : correlation with Anaktuvuk sequence farther $\mathrm{N}$ indicates that deglaciation at sample locality may be as recent as ca. $7500 \mathrm{yr}$. Only other possible correlation is with the recession from the maximum Itkillik advance, probably no earlier than 18,000 B.p. in the Anaktuvuk area. Wood, therefore, is probably of preItkillik interstadial age, redeposited.

\section{Kotzebue Sound series, Alaska}

Wood and twigs coll. from sea cliffs of Baldwin Peninsula, from $\mathrm{N}$ shore of Selawik Lake, and from river bluffs in the Kobuk delta, Alaska. Coll. 1961. by D. M. Hopkins, D. S. McCulloch, and R. J. Janda; subm. by D. M. Hopkins. Comment (D.M.H.) : sites of samples W-1249, W-1250, and W-1255 are now tundra; dates indicate, therefore, a late-Wisconsin to early Recent warm period. Since soil which truncates top of ice-wedge cast from which W-1254 was coll. is thought to have been formed during this warm period, W-1254 is maximum for that period. W-1257 is thought to have been deposited during Wisconsin time. Ice-wedge cast truncating loess above W-1257, from which W-1262 was 
coll., is thought to represent local ice-wedge melting of Wisconsin age, as does W-1256. W-1252 is thought to represent Illinoian or late Illinoian-age floodplain of Kobuk River. W-1253 is thought to represent a buried Sangamon-age forest. Ice wedge from which W.1251 was coll. is thought to have been formed during a slight lowering of sealevel in Sangamon time.

\section{W-1249. Log from beaver dam}

$8550 \pm 400$

6600 в.C.

Log from beaver dam (birch, cottonwood, and spruce up to $3 \mathrm{in}$. in diam) buried beneath $8 \mathrm{ft}$ of sphagnum peat. W coast of Baldwin Peninsula $\left(66^{\circ} 36^{\prime}\right.$ $12^{\prime \prime} \mathrm{N}$ Lat, $162^{\circ} 05^{\prime} 00^{\prime \prime}$ W Long $)$.

\section{W-1255. Wood from pond sediments}

$9020 \pm 350$ 7070 в.с.

Wood coll. from sea cliffs ne'ar Cape Blossom, Baldwin Peninsula $\left(66^{\circ} 43^{\prime}\right.$ $51^{\prime \prime} \mathrm{N}$ Lat, $162^{\circ} 26^{\prime} 54^{\prime \prime} \mathrm{W}$ Long), from pond peat containing snails and roots in silt $6 \mathrm{ft}$ alove beach.

\section{W-1250. Wood from lake sediments}

$7270 \pm 350$

5320 в.C.

Wood from sea cliffs $N$ of Cape Blossom, Baldwin Peninsula (66 $44^{\prime} 22^{\prime \prime}$ $\mathrm{N}$ Lat, $162^{\circ} 30^{\prime} 02^{\prime \prime} \mathrm{W}$ Long), coll. from thaw-lake sediments containing large logs, some beaver-chewed, and large freshwater pelecypods. overlying silt, and till of Illinoian age.

\section{W-1254. Wood from ice-wedge cast}
$11,340 \pm 400$
9390 в.c.

Wood from ice-wedge cast, SW shore Baldwin Peninsula $\left(66^{\circ} 40^{\prime} 28^{\prime \prime} \mathrm{N}\right.$ Lat, $162^{\circ} 09^{\prime} 10^{\prime \prime} \mathrm{W}$ Long). Stratigraphy, top to bottom: recent turf; unoxidized peaty silt; humified peat and peaty silt; soil horizon; peaty laminated sand and silt with wood (sample) in collapse filling; humified peat; laminated silt with deformed bedding; peaty silt and peat; massive silt.

\section{W-1256. Twigs from peat-filled ice-wedge cast}

Twigs from peat-filled ice-wedge cast ca. $5 \mathrm{ft}$ above beach, $W$ shore of Baldwin Peninsula $\left(66^{\circ} 40^{\prime} 47^{\prime \prime} \mathrm{N}\right.$ Lat, $162^{\circ} 09^{\prime} 40^{\prime \prime} \mathrm{W}$ Long). Ice-wedge cast overlain by $25 \mathrm{ft}$ of stratified silt, with freshwater mollusks, that hecomes peatrich in upper portion.

\section{W-1257. Twigs from silt}

$>38,000$

Twigs from frost-contorted silt with humified peat, $\mathbb{W}$ shore Baldwin Peninsula ( $66^{\circ} 41^{\prime} 56^{\prime \prime} \mathrm{N}$ Lat, $162^{\circ} 12^{\prime} 01^{\prime \prime}$ W Long) ; covered by $8 \mathrm{ft}$ of loess and lake deposits truncated by ice-wedge cast from which W-1262 was coll.

\section{W-1262. Twigs from ice-wedge cast \\ $34,000 \pm 2000$ 32,050 в.с.}

Twigs from ice-wedge cast that truncates water-laid loess of Wisconsin age, W shore Baldwin Peninsula (66 41' 56" N Lat, $162^{\circ} 12^{\prime} 01^{\prime \prime}$ W Long). Jce-wedge cast also contains willow leaves and freshwater mollusks, and is overlain by water-laid silt. 


\section{W-1252. River bluff twigs}

Twigs in interbeded finc sand and silt from river bluff on Riley Creek channel of Kobuk River ( $66^{\circ} 53^{\prime} 04^{\prime \prime} \mathrm{N}$ Lat, $161^{\circ} 24^{\prime} 12^{\prime \prime}$ W Long).

W-1253. Log

Logs from Cape Blossom, Baldwin Peninsula $\left(66^{\circ} 43^{\prime} 50^{\prime \prime} \mathrm{N}\right.$ Lat, $162^{\circ} 28^{\prime}$ $12^{\prime \prime}$ W Long), directly overlying till of Illinoian age and overlain by woody peat and silt.

\section{W-1251. Wood}

$>42,000$

Wood from ice-wedge cast that penetrates fossiliferous marine brach sand and that is covered by marine beach sand; shore of Eschscholtz Bay, Baldwin Peninsula ( $66^{\circ} 23^{\prime} 47^{\prime \prime}$ N Lat, $161^{\circ} 35^{\prime} 11^{\prime \prime}$ W Long) .

\section{W-1304. Tolsona Creek, Alaska}

$5850 \pm 320$ 3900 в.с.

Peat from E side Tolsona Creek, 1/4 mi S of Mile 172.5 Glenn Highway $\left(62^{\circ} 05^{\prime} 30^{\prime \prime} \mathrm{N}\right.$ Lat, $145^{\circ} 57^{\prime} 50^{\prime \prime} \mathrm{W}$ Long), Alaska. From undisturbed thin basal layer of several peat beds interlayered with sand, overlying contorted alluvial gravel with a thin peat bed (W-717, USGS V). Gravel overlies clear ice $>1 \mathrm{~m}$ thick and $3 \mathrm{~m}$ long, which is in upper part of a bed of pebbly silty lacustrine clay. Coll. 1954 and subm. by D. R. Nichols. Comment (D.R.N.) : a period in which an ice mass formed in top of lacustrine clay, causing contor. tion of overlying gravel, was followed by bog and quiet-water environment. Samples W-717, $6910 \pm 250$ (USGS V) and W-1304 bracket a cold period favorable to growth of a large mass of ground ice (Nichols, 1964). Subsequent climate also was cold, because permafrost continued to grow upward into overlying sand and peat.

\section{E. Miscellaneous}

\section{W-1336. Port Campbell, Australia}

$7380 \pm 250$ $\mathbf{5 4 3 0}$ в.C.

Carbonaceous matter taken along track from Loch Ard entry to Sherbrook River, E of Port Campbell ( $38^{\circ} 37^{\prime} \mathrm{S}$ Lat, $143^{\circ} 04^{\prime} \mathrm{E}$ Long), Victoria, Australia. Coll. from hardpan under soil overlying Pliocene clay and Miocene limestone. Underlies zone containing australites. Coll. 1963 by E. D. Gill; subm. by E. C. T. Chao. Comment: date possibly maximum for australites.

\section{W-1415. Amazon Basin, Brazil}

$1460 \pm 200$

Wood from tree trunk buried by recent alluvium on right bank of main channel of Rio Solimoes, Itha do Cariero near Manaus $\left(3^{\circ} 11^{\prime} \mathrm{S} \mathrm{Lat}, 59^{\circ} 53^{\prime}\right.$ W Long), Amazonas, Brazil. Coll. 1963 and subm. by R. E. Oltman. Comment (R.E.O.) : tree was killed when deposition occurred in back swamp as the natural levee on periphery of Careiro Island advanced E during normal channel migration of Rio Solimoes. Dates rate of channel migration.

W-1272. Curitiba, Brazil

$2420 \pm 200$ 470 в.c.

Carbonized wood in alluvium from Curitiba, Paraná $\left(25^{\circ} 30^{\prime} \mathrm{S}\right.$ Lat, $49^{\circ}$ 10' W Long), Brazil. Coll. 1962 by R. G. Reeves and J. J. Bigarella; subm. by 
R. C. Reeves. Comment: wood dates last climatic change in the area, from dry to moist.

\section{W-1378. Ivar Baardsöns Glacier, Greenland}

$$
\begin{array}{r}
1490 \pm 250 \\
\text { A.D. } 460
\end{array}
$$

Turf from $N$ edge of moraine of Ivar Baardsöns Glacier, Schuchert Dal $\left(71^{\circ} 30^{\prime} \mathrm{N}\right.$ Lat, $24^{\circ} 30^{\prime} \mathrm{W}$ Long). East Greenland. Turf buried in glacial drift consists of silty sand with mat of stems and roots. Coll. 1962 and subm. by J. P. Schafer. Comment (J.P.S.) : date confirms that "fresh" moraines are not all from the last three centuries, as had heen supposed.

\section{W-1381. Schuchert Dal, Greenland}

$7900 \pm 350$ 5950 в.с.

Fragments of shells, mostly Mya truncata from $\mathbb{W}$ side of Schuchert Dal, $2 \mathrm{~km} \mathrm{~S}$ of moraine of Ivar Baardsöns Glacier $\left(71^{\circ} 30^{\prime} \mathrm{N}\right.$ Lat, $24^{\circ} 30^{\prime} \mathrm{W}$ Long), East Greenland. Coll. on surface of 50-m marine terrace, formed when Schuchert Dal here was a bay. Coll. 1962 by J. P. Schafer and J. H. Hartshorn; subm. by J. P. Schafer. Comment (J.P.S.) : date fits reasonably well with Washburn and Stuiver's curve of postglacial uplift from Mesters Vig area to the $\mathrm{N}$ (Washburn and Stuiver, 1962).

\section{W-1426. Shippersea Bay, County Durham, England $\quad>38,000$}

Marine shells from $\mathbb{W}$ end of Shippersea Bay, near Hawthorne, County Durham $\left(54^{\circ} 48^{\prime} \mathrm{N}^{\prime}\right.$ Lat, $1^{\circ} 19^{\prime} \mathrm{W}$ Long), England. From $15 \mathrm{ft}$ of gravel on bench cut into bedrock, base of deposit at alt $90 \mathrm{ft}$. Coll. 1964 by J. Pattison; subm. by D. B. Smith, Geol. Survey of Great Britain, Leeds. Comment (D.B.S.) : deposit originally thought postglacial, but field relations suggest interglacial or interstadial age, supported hy date. Date also is minimum for local lower till.

\section{W-1460. Small Water, Westmorland, Fngland $\quad \mathbf{8 4 5 0} \pm 350$ \\ 6500 в.C.}

Core sample of organic mud from small corrie lake at Small Water, Westmorland $\left(54^{\circ} 20^{\prime} \mathrm{N}\right.$ Lat, $2^{\circ} 50^{\prime} \mathrm{W}$ Long), England. From 450 to $456.5 \mathrm{~cm}$ depth in core at boundary between organic layers above and glacial clay, silt, and sand at base. Coll. 1964 and subm. by Winifred Tutin, The University, Leicester, England. Comment (W.T.) : date is minimum for last occupation of this corrie by ice and substantiates pollen evidence that the corrie was so occupied during final episode of last glaciation. Agrees well with date of deposits with the same pollen spectrum at Scalehy Moss; that of Zone VIa on Godwin's British zonation scheme (Q-161, $9009 \pm$ 194. Cambridge I).

\section{W-1211. Makua Valley, Oahu, Hawaii \\ $5580 \pm \mathbf{3 0 0}$ \\ 3630 в.C.}

Wood from well $600 \mathrm{ft} \mathrm{E}$ of shoreline ca. $60 \mathrm{ft}$ below sealevel, Makua Valley, Western (Oahu $\left(21^{\circ} 32^{\prime} \mathrm{N}\right.$ Lat, $158^{\circ} 15^{\prime} \mathrm{W}$ Long), Hawaii. Coll. 1962 and subm. by C. P. Zones. Comment. (C.P.Z.) : dates Waipio stand of the sea (Stearns and Vaksik, 1935).

\section{W-1341. Nahal Mishmar, Israel}

$4880 \pm 250$ 2930 B.C.

Fragments of reed mat found in Cave A, Nahal Mishmar, vicinity of Dead 
Sea ( $31^{\circ} 15^{\prime} \mathrm{N}$ Lat, $35^{\circ} 23^{\prime} \mathrm{E}$ Long), Israel. Mat contained copper-alloy objects of high technical standard of workmanship (Bar-Adon, 1962). Coll. 1961 and subm. by P. Bar-Adon, Dept. Antiquities, Jerusalem, Israel. Comment (P.B.A.) : material belongs to end of Chalcolithic (end of 4th Millennium B.c.). Other determinations on parts of same reed mat are I-285, $4780 \pm 100$ (Isotopes, unpuh.) and BM-140, $5390 \pm 150$ (British Museum, unpub.).

W-1240. Dalat, Viet Nam

\section{$1850 \pm 350$ A.D. 100}

Carbonaceous plant material overlying tektite-bearing limonitic gravel, from reactor site at Dalat ( $11^{\circ} 57^{\prime} \mathrm{N}$ Lat, $108^{\circ} 27^{\prime} \mathrm{E}$ Long), Viet Nam. Coll. 1962 and subm. by E. T. C. Chao. Comment: date is minimum for tektite.

Date lists:

\section{REFERENCES}

Cambridge 1

Isotopes III

USGS IV

USGS $V$

USGS VI

USGS VII

Univ. of Washington I Dorn et al, 1962

\author{
Godwin and Willis, 1959 \\ Trautman, 1963 \\ Rubin and Alexander, 1958 \\ Rubin and Alexander, 1960 \\ Rubin and Berthold, 1961 \\ Ives et al., 1964
}

Armstrong, J. E., Crandell, D. R., Easterhrook, D. J., and Noble, J. B., in press, Late Pleistocene stratigraphy and chronology in southwestern British Columbia and northwestern Washington: Geol. Soc. America Bull.

Bar-Adon, Pessah, 1962, Expedition C-the cave of the treasure: Israel Exploration Jour., v. 12, p. $215-226$.

Blackwelder, Eliot, 1915, Cretaceous history of the mountains of central western Wyoming: Jour. Geology, v. 23, p. 97-117, 193-217, 307-340.

Bradley, W. C., 1956, Carbon-14 date for marine terrace at Santa Cruz, California: Geol. Soc. America Bull., v. 67, p. 675-67\%.

Crandell, D. R., Mullineaux, I). R., Miller, R. D., and Rubin, Meyer, 1962, Pyroclastic deposits of recent age at Mount Rainier, Washington: U. S. Geol. Survey Prof. Paper 450-D, p. D64-D68.

Curray, J. R., 1961, Late Quaternary sea level: a discussion: Geol. Soc. America Bull., v. 72, ค. 1708 .

Detterman, R. L., Bowsher, A. L., and Dutro, J. T., 1958, Glaciation on the Arctic slope of the Brooks Range, northern Alaska: Arctic, v. 11, p. 43-61.

Dorn, T. F., Fairhill, A. W., Schell, W. R., and Takashima, Y., 1962, Radiocarbon dating at the University of Washington I: Radiocarbon, v. 4, p. 1-12.

Ferrians, O. J., Jr., 1963, Glaciolacustrine diamicton deposits in the Copper River Basin, Alaska: U. S. Geol. Survey Prof. Paner 475-C, p. C121-C125.

Ferrians, O. J., Jr., and Schmoll, H. R., 1957, Extensive proglacial lake of Wisconsin age in the Copper River Basin, Alaska: Geol. Soc. America Bull., v. 69, p. 1563.

Fisk, H. N., and McFarlan, F., Jr., 1955, Late Quaternary deltaic deposits of the Mississippi River: Geol. Soc. America special paper 62, p. 279-302.

Fisk, H. N., Richards, H. C., Brown, C. A., and Steere, W. C., 1938, Contributions to the Pleistocene history of the Florida parishes of Louisiana: Louisiana Dept. Conserv., Geol. Bull., v. 12, 137 p.

Flint, R. F., and Gale, W. A., 1958, Stratigraphy and radiocarbon dates at Searles Iake, California: Am. Jour. Sci., v. 256, p. 689-714.

Godwin, H., and Willis, E. H., 1959, Cambridge University natural radiocarbon measurements I: Radiocarbon, v. 1, p. 63-75.

Hopkins, D. M., 1960, History of Imuruk Lake, Seward Peninsula, Alaska: Geol. Soc. America Bull., v. 70, p. 1033-1046.

1963, Geology of the lmuruk Lake area, Seward Peninsula, Alaska: U. S. Geol. Survey Bull. 1141-C, 101 p. [1964\}.

Hopson, C. A., Waters, A. C., Bender, V. R., and Rubin, Meyer, 1962, The latest eruptions from Mount Rainier volcano: Jour. Geology, v. 70, 1. 635-647.

Ives, P. C., Levin, Betsy, Robinson, R. D., and Rubin, Meyer, 1964, U. S. Geological Survey radiocarbon dates VII: Radiocarbon, v. 6, p. 37-76. 
Jennings, J. D., and Norbeck, Edward, 1955, Great Basin pre-history: a review: Am. Antiquity, v. 21, p. 1-11.

Kume, Jack, and Hansen, D. F., 1964, The geology of Burleigh County: North Dakota Geol. Survey Bull. 42.

Love, J. D., and Taylor, D. W., 1962, Faulted Pleistocene strata near Jackson, northwestern Wyoming: U. S. Geol. Survey Prof. Paper 450-D, p. D136-D139.

Miller, D. J., 1953, Late Cenozoic marine glacial sediments and marine terraces of Middleton Island, Alaska: Jour. Geolory, v. 61, no. 1, p. 17-40.

MuIlineaux, D. R., Waldron, H. H., and Rubin, Meyer, 1965, Stratigraphy and chronology of Late Interglacial and early Vashon glacial time in the Seattle area, Washington: U. S. Geol. Survey Bull. 1194-0.

Nichols, 1). R., in press, Permafrost in the Recent epoch; in Internation Symposium on Permafrost: Natl. Acad. Sci. Research Advisory Board.

Porter, S. C., 1964, Late Pleistocene glacial chronology of the north-central Brooks Range, Alaska: Am. Jour. Sci., v. 262, 1. 446-460.

Redfield, A. C., and Rubin, Meyer, 1962, The age of the salt marsh peat and its relation to recent changes in sea level at Barnstable, Massachusetts: U. S. Natl. Acad. Sci. Proc., v. 48, p. $1728-1735$.

Rubin, Meyer, and Alexander, Corrinne, 1958, U. S. Geological Survey radiocarbon dates IV: Science, v. 127, p. 1476-1487.

Rubin, Meyer, and Alexander, Corrinne, 1960, U. S. Geological Survey radiocarbon dates V: Am. Jour. Sci. Radioc. Supp., v. 2, p. 129-185.

Rubin, Meyer, and Berthold, S. M., 1961, U. S. Geological Survey radiocarbon dates VI: Am. Jour. Sci. Radioc. Supp., v. 3, p. 86-98.

Ruhe, R. V., 1962, Age of the Rio Grande Valley in Southern New Mexico: Jour. Geology, v. 70 , 1. 151-167.

Smith, G. l., 1960, Time of the last displacement on the middle part of the Garlock fault, California: U. S. Geol. Survey Prof. Paper 400 B, p. B280.

Stearns, H. T., and Vaksvik, K. N., 1935, Geoloyy and ground-water resources of the island of. Oahu, Hawaii: Hawaii Div. Hydrography Bull. 1,479 p.

Trautman, Milton A., 1963, Isotopes, Inc. radiocarbon measurements III: Radiocarbon, v. 5, p. $63-79$.

Upham, Warren, 1895, The Glacial Lake Agassiz: U. S. Geol. Survey Monograph 25.

Washburn, A. L., and Stuiver, Minze, 1962, Radiocarbon-dated postglacial delevelling in NE Greenland: Aretic, v. 15, p. 66- 73 .

Wright, H. F.. Jr., 1962, The role of the Wadena lobe in the Wisconsin glaciation of Minnesota: Geol. Soc. America Bull., v. 73, p. 73-100. 